\title{
Genetically modified crops and aquatic ecosystems: considerations for environmental risk assessment and non-target organism testing
}

\author{
Keri Carstens • Jennifer Anderson • Pamela Bachman • Adinda De Schrijver • \\ Galen Dively • Brian Federici • Mick Hamer • Marco Gielkens • Peter Jensen • \\ William Lamp · Stefan Rauschen • Geoff Ridley • Jörg Romeis • Annabel Waggoner
}

Received: 19 April 2011/Accepted: 7 October 2011/Published online: 26 November 2011

(C) The Author(s) 2011. This article is published with open access at Springerlink.com

\begin{abstract}
Environmental risk assessments (ERA) support regulatory decisions for the commercial cultivation of genetically modified (GM) crops. The ERA for terrestrial agroecosystems is well-developed, whereas guidance for ERA of GM crops in aquatic ecosystems is not as well-defined. The purpose of this document is to demonstrate how comprehensive problem formulation can be used to develop a
\end{abstract}

The contents of this paper reflect the thoughts and opinions of the authors and do not represent an official policy statement from the U.S. Environmental Protection Agency or other federal government agencies. Any mention of a product does not constitute an endorsement by the U.S. federal government.

K. Carstens $(\bowtie) \cdot$ J. Anderson

Regulatory Science, Pioneer Hi-Bred, DuPont

Agricultural Biotechnology, 2450 SE Oak Tree Ct.,

Ankeny, IA 50021, USA

e-mail: keri.carstens@pioneer.com

J. Anderson

e-mail: jennifer.anderson@pioneer.com

\section{P. Bachman · P. Jensen}

Monsanto Company, 800 North Lindbergh Blvd., St.

Louis, MO 63167, USA

e-mail: pamela.m.bachman@monsanto.com

P. Jensen

e-mail: peter.d.jensen@monsanto.com

\section{A. De Schrijver}

Scientific Institute of Public Health, Juliette Wytsmanstraat 14, 1050 Brussels, Belgium e-mail: Adinda.DeSchrijver@wiv-isp.be conceptual model and to identify potential exposure pathways, using Bacillus thuringiensis (Bt) maize as a case study. Within problem formulation, the insecticidal trait, the crop, the receiving environment, and protection goals were characterized, and a conceptual model was developed to identify routes through which aquatic organisms may be exposed to insecticidal proteins in maize tissue. Following a tiered approach for exposure assessment, worst-case exposures were estimated using standardized models, and factors mitigating exposure were described. Based on exposure estimates, shredders were identified as the functional group most likely to be exposed to insecticidal proteins. However, even using worst-case

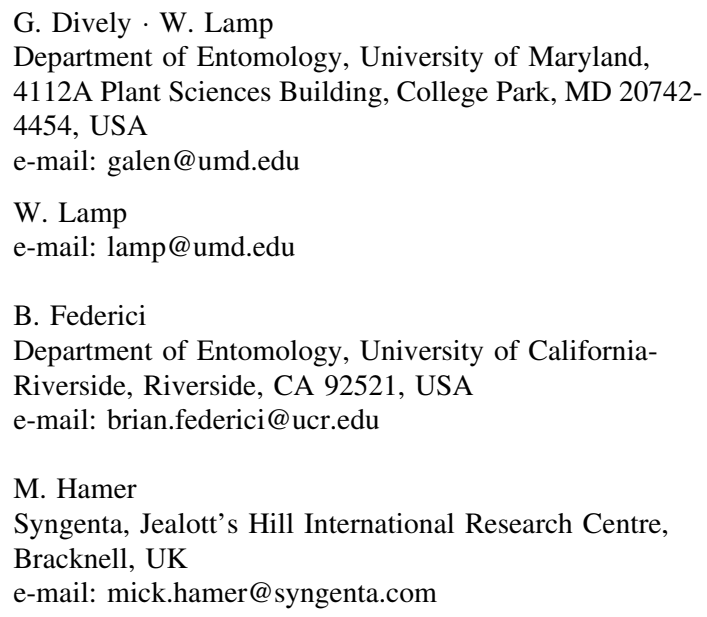


assumptions, the exposure of shredders to Bt maize was low and studies supporting the current risk assessments were deemed adequate. Determining if early tier toxicity studies are necessary to inform the risk assessment for a specific GM crop should be done on a case by case basis, and should be guided by thorough problem formulation and exposure assessment. The processes used to develop the Bt maize case study are intended to serve as a model for performing risk assessments on future traits and crops.

Keywords Environmental risk assessment - Aquatic ecosystem · Non-target organism · Genetically modified crops

\section{Introduction}

Aquatic environments support a wide range of ecological functions and ecosystem services (Jackson et al. 2001). Not only do they assimilate and cycle nutrients and carbon, they also maintain biodiversity, support primary and secondary biomass production, as well as provide habitat and food resources for aquatic and terrestrial food webs (Cummins et al. 1989; Allan and Castillo 2007). Aquatic ecosystems are influenced in many ways by inputs from the surrounding landscape, and agricultural watersheds in particular may be dramatically altered by anthropogenic disturbances over time (Cronan et al. 1999; Lenat and Crawford 1994). Because disturbance can lead to profound effects on biotic community structure and function, protection and conservation of aquatic ecosystem services is paramount. Consequently, aquatic ecosystems need to be considered in the environmental risk assessment (ERA) of plant protection products, such

M. Gielkens

National Institute for Public Health and the Environment, Expertise Centre for Substances, PO Box 1, 3720 BA

Bilthoven, The Netherlands

e-mail: Marco.Gielkens@rivm.nl

S. Rauschen

Institute for Biology III (Plant Physiology), RWTH

Aachen University, Worringerweg 1, 52074 Aachen,

Germany

e-mail: rauschen@bio3.rwth-aachen.de

\section{G. Ridley}

Environmental Risk Management Authority, PO Box 131, Wellington 6140, New Zealand

e-mail: geoff.ridley@ermanz.govt.nz as pesticides and genetically modified (GM) crops that have insecticidal traits.

Over the past few decades, significant advances have been made in the field of biotechnology, and the cultivation of GM crops is steadily increasing worldwide (James 2009). Because insecticidal proteins from GM crop fields may enter aquatic systems, the potential effect that GM crops may have on those ecosystems is considered in the ERA. Insecticidal proteins within currently commercialized GM crops are known to be rapidly inactivated in the terrestrial environment (Herman et al. 2001; Head et al. 2002; Icoz and Stotzky 2008; Prihoda and Coats 2008b; Clark et al. 2005; Li et al. 2007; Marchetti et al. 2007; Accinelli et al. 2008; Miethling-Graff et al. 2010; Zurbrügg et al. 2010). However, fewer studies have addressed the potential exposure of aquatic ecosystems to GM plant material or transgene products (Prihoda and Coats 2008a; Douville et al. 2007; Raybould et al. 2007; Rosi-Marshall et al. 2007; Griffiths et al. 2009; Swan et al. 2009; Pote et al. 2009; Jensen et al. 2010; Wolt and Peterson 2010; Tank et al. 2010). Likewise, few studies have assessed the potential impacts of insecticidal GM crops on aquatic organisms (Rosi-Marshall et al. 2007; Beachy et al. 2008; Parrott 2008; van Frankenhuyzen 2010; Jensen et al. 2010), and these studies have been limited to maize expressing proteins derived from the common soil bacterium, Bacillus thuringiensis (Bt).

Where spectrum of activity is narrow and welldefined (e.g. current GM crops containing insecticidal proteins), or in cases where exposure is determined to be very low, a conclusion about risk can be reached with either adequate hazard testing or preliminary exposure characterization. To date, due to the narrow

\section{J. Romeis \\ Agroscope Reckenholz-Tänikon Research Station ART, Reckenholzstr. 191, 8046 Zurich, Switzerland e-mail: joerg.romeis@art.admin.ch}

\section{A. Waggoner}

US Environmental Protection Agency, Office of Pesticide Programs, Biopesticides and Pollution Prevention Division, 1200 Pennsylvania Avenue NW, Mail Code: 7511P, Washington, DC 20460-0001, USA e-mail: waggoner.annabel@epa.gov 
spectra of activity of $\mathrm{Bt}$ and VIP proteins in currently commercialized GM crops, aquatic ERAs have been based on worst-case exposure models, such as the US EPA's Generic Estimated Environmental Concentration (GENEEC) model (e.g., US EPA 2004; Raybould and Vlachos 2011; Wolt and Peterson 2010), and effects tests using Daphnia magna (Cladocera: Daphniidae) (OECD 2007). These risk assessments have been deemed satisfactory by regulatory agencies (e.g., US EPA 2001). Should transgenic products be introduced with the potential for broad-spectrum activity, a re-evaluation of potentially sensitive aquatic species and appropriate surrogate test organisms may be warranted based on refined aquatic exposure estimates. These exposure refinements could be based on the degree to which aquatic ecosystems are exposed to crop residues and could be used to determine whether environmental exposures approach the levels that have adverse effects in hazard studies (Romeis et al. 2011; Rose 2007; Wolt and Peterson 2010). In these circumstances, the amount of crop biomass, the concentration of transgenic proteins that enter aquatic systems, and the temporal and spatial overlap of crop residue inputs with the presence of sensitive species may require further characterization to help inform the risk assessment.

Governmental regulatory agencies have adopted a tiered approach for assessing the risk of conventional chemical pesticides and biopesticides (i.e., plantprotection products) to non-target organisms (NTOs) in terrestrial environments (US EPA 1998; CAC 2001). The tiered approach was also determined to be applicable for assessing the risk of GM crops (US EPA 2001; Garcia-Alonso et al. 2006; Rose 2007; Romeis et al. 2008). While tests have been requested to assess the risk to aquatic non-target organisms on a case by case basis under conditional registrations, guidelines for conducting early-tiered toxicity tests with aquatic NTOs would benefit from clarification and standardization. There is opportunity to improve guidance for aquatic organism species selection that is based on exposure characterization and extends the surrogate species concept used currently in terrestrial ERA. The goal of this paper is to help guide the ERA approach by demonstrating how comprehensive problem formulation can help identify the potential risks associated with cultivation of transgenic crops near aquatic systems. A conceptual model, using transgenic maize as a case study, was developed to aid in exposure characterization, and significant routes through which aquatic organisms may be exposed to insecticidal proteins expressed in maize are discussed. We chose $\mathrm{Bt}$ maize as a case study because of the wealth of data available on concentrations of Bt in planta throughout the growing season, as well as accessibility of risk assessment data; however, to date the ERA approach (i.e., worst-case exposure models and early-tier hazard testing with Daphnia magna) has adequately assessed the risks associated with cultivation of Bt maize. The logic presented in development of the case study conceptual model is intended to be applied to future products. Factors mitigating exposure are also discussed because they are key considerations for determining realistic exposure estimates. Using the transgenic maize case study, we make recommendations for the selection of aquatic surrogate species for early tier laboratory studies that may be more appropriate for hazard studies for future insecticidal traits. Additional areas of research are also highlighted that may inform the exposure assessment of those traits. The recommendations discussed herein are designed to be applied to other crops as well as future traits.

\section{Problem formulation}

Environmental risk assessment is a process that regulatory authorities use to assess the likelihood of adverse effects on populations and communities of organisms in the environment. ERA is a science-based process in which the risk of introducing a new GM crop into the environment is quantified using a welldefined, hypothesis-driven approach. In this light, ERA is clearly distinguished from exploratory or basic research in that ERA follows an established process that is designed to answer specific questions about the risk of cultivating GM crops in the environment (Raybould 2006, 2010). The framework for ERA distinctly outlines the process of risk assessment, which includes three main stages: problem formulation, analysis, and risk characterization (US EPA 1998). Problem formulation is multifaceted, in that risk assessors must consider not only the context of the GM crop but also the many factors that play into that context, including characteristics of the trait, the ecosystem in which the GM crop will be released, and protection goals set by policies (Raybould 2006; Wolt 
et al. 2010; Carstens et al. 2010). The central focus of the problem formulation process is the identification of potential risk by defining harm and its likelihood of occurrence in the context of the proposed GM crop and receiving environment. The first step in problem formulation is the review of information available on the trait and crop in question. Box 1 details the process of problem formulation, including specific considerations and outcomes that further inform the risk assessment.

Description of trait characteristics

'Genetically modified crop' is a broad term that encompasses a variety of agricultural crops that have had one or more genes inserted by the use of genetic

Box 1 Key steps in problem formulation (adapted from Carstens et al. 2010)

\section{Problem Formulation}

Review of available data

* Description of Trait Characteristics

$>$ Is the GM product substantially equivalent to its conventional counterpart?

- Comparisons of molecular, compositional, and agronomic characteristics of the GM product with its conventional counterpart will allow focusing of the ERA on the introduced changes

$>$ Is the introduced change an insecticidal trait?

- If yes, then insects are more likely to be affected than other non-target organisms.

- What is the specificity of the trait?

- Organisms that are closely related to the sensitive target organism(s) are more likely affected than other more distantly related species

$>\quad$ If not an insecticidal trait, then what are the characteristics that are of concern?

* Description of Receiving Environment

Is the application for cultivation of the crop?

- If yes, then the risk assessment should focus on the agroecosystem appropriate for that crop (e.g. a maize field or rice paddy, and immediate surrounding area)

- What are the characteristics of the crop and related agricultural practices? How might they impact the fate of plant material, and the fate of the trait?

- Which organisms might occur within the receiving environment?

- If the application is for import of grain, then the trait will be very limited in its release in the environment.

* Protection goals

$>$ Regulatory decision regarding entities to be protected

- Examples generally include species that are valued, i.e., endangered species or species that provide important ecosystem services

- Identification of assessment endpoints and determination of measurement endpoints, as defined by US EPA (1998) and Wolt et al. (2010)

$>$ Definition of harm-how do we know if an effect that is observed can be considered adverse?

- Is 50\% growth inhibition harm? What level of mortality would be significant for a population? (Rose 2007)

Actions

* Develop conceptual model

$>$ Identify exposure pathways related to how the stressor could cause harm to the assessment endpoint

* Generate risk hypotheses

$>$ Based on the protection goals, and characteristics of the trait and agroecosystem, what areas of concern have been identified?

$>$ Are existing risk assessment data available on the trait in question?

- If yes, then use those data to inform the new ERA

- If not, then formulate testable hypotheses, e.g. the stressor does not harm non-target organisms at environmentally relevant concentrations

* Determine analysis plan

$>\quad$ What data are needed to test the risk hypotheses with maximum rigor? 
engineering techniques. The specific gene(s) inserted, their biological and toxicological function, and expression at various developmental stages in planta differs from product to product; the inserted genes are chosen to produce crops with agronomically or nutritionally desirable traits. To date, the most commonly expressed traits confer herbicide tolerance and insect resistance. Several crops (maize, soybean, rapeseed, cotton and sugar beet), have been engineered for tolerance to broad-spectrum herbicides, namely glyphosate or glufosinate-ammonium. Future traits conferring glyphosate and glufosinate-ammonium tolerance in other crops are being developed, as are traits conferring tolerance to other herbicides.

Currently, insect-resistance in crops is based on expression of crystalline (Cry) proteins and vegetative insecticidal proteins (e.g., Vip3A) following insertion of $\mathrm{Bt}$ genes. There are numerous variations of $\mathrm{Bt}$ proteins, each of which act against a narrow set of insect pests (e.g., Lepidoptera, Coleoptera, or Diptera larvae; see review by Clark et al. 2005) in a range of crops. In addition to traits conferring tolerance to herbicides and resistance to insects, a wide variety of additional traits are being developed. Among others, these traits include drought tolerance, improved nutrient composition, improved yield, stress tolerance, modified enzyme expression for use in the biofuel industry (Wolt 2009), and improved digestibility. Future insect active technologies may include RNA interference (Baum et al. 2007), and other insecticidal proteins such as protease inhibitors, $\alpha$-amylase inhibitors, or lectins (Malone et al. 2008). New and emerging technologies will further broaden the definition of GM crops; therefore, risk assessments for transgenic crops should be conducted on a case by case basis.

In the process of problem formulation, one has to ask how the GM crop could cause harm to the receiving environment in order to formulate hypotheses that adequately address potential risk. For instance, a trait that produces an output trait enzyme is unlikely to yield significant risk to NTOs; in contrast, an insecticidal protein will need further examination of risk (Raybould et al. 2010). For GM crops, data available early in the product development process should be used to help inform problem formulation. In the case of currently commercialized insect-resistant GM crops, compositional and agronomic analysis of plant material throughout the growing season has thus far revealed no meaningful differences when comparing the transformed event with its conventional counterpart (e.g., near-isoline) (Herman et al. 2009; Taylor et al. 1999; Ridley et al. 2002; George et al. 2004). Therefore, the risk assessment can typically focus on the inserted gene and resultant insecticidal protein as the stressor of concern, since in all other ways the GM crop is substantially equivalent to the isoline (i.e., within the limits of the natural variation observed in the isoline crop composition). Additional information on the specificity and expression of the insecticidal trait will further refine the risk hypotheses formed during problem formulation. For example, depending on the promoter used, some Bt crops do not express Bt protein in pollen, thus negating exposure to NTOs via pollen. Furthermore, if $\mathrm{Bt}$ maize is known to express a Coleoptera-specific $\mathrm{Bt}$ protein, it is logical to focus the risk assessment on valued non-target Coleoptera (e.g., predators such as Coccinellidae). In this case, if bioassay data indicate biological activity is restricted to pests of the Chrysomelidae family, the protein does not show activity on non-target terrestrial beetles, and the level of exposure to aquatic beetles is determined to be low and transient, then additional effects testing on aquatic beetles may not be required to adequately assess risk. These examples demonstrate how a stepwise approach and a thorough understanding of trait characteristics help risk assessors to focus on areas of specific concern or uncertainty, which results in a more focused analysis plan to better inform the ERA.

\section{Description of the receiving environment}

In the case of GM crops, the receiving environment is the agricultural field in which the crop is planted, as well as the immediate surrounding area (including aquatic ecosystems adjacent to the field). Aquatic ecosystems within an agricultural landscape can take many forms including ephemeral wetlands, farm ponds, and natural or man-made streams/ditches. These water bodies may contain abundant and diverse invertebrate communities (Davis et al. 2003; Moore and Palmer 2005; Heatherly and Whiles 2007; Menninger and Palmer 2007; Herzon and Helenius 2008), and contribute to the decomposition of vegetation debris (Swan and Palmer 2004).

The breakdown of organic matter (e.g., senesced leaves) in water bodies (Fig. 1) is a critical ecological 


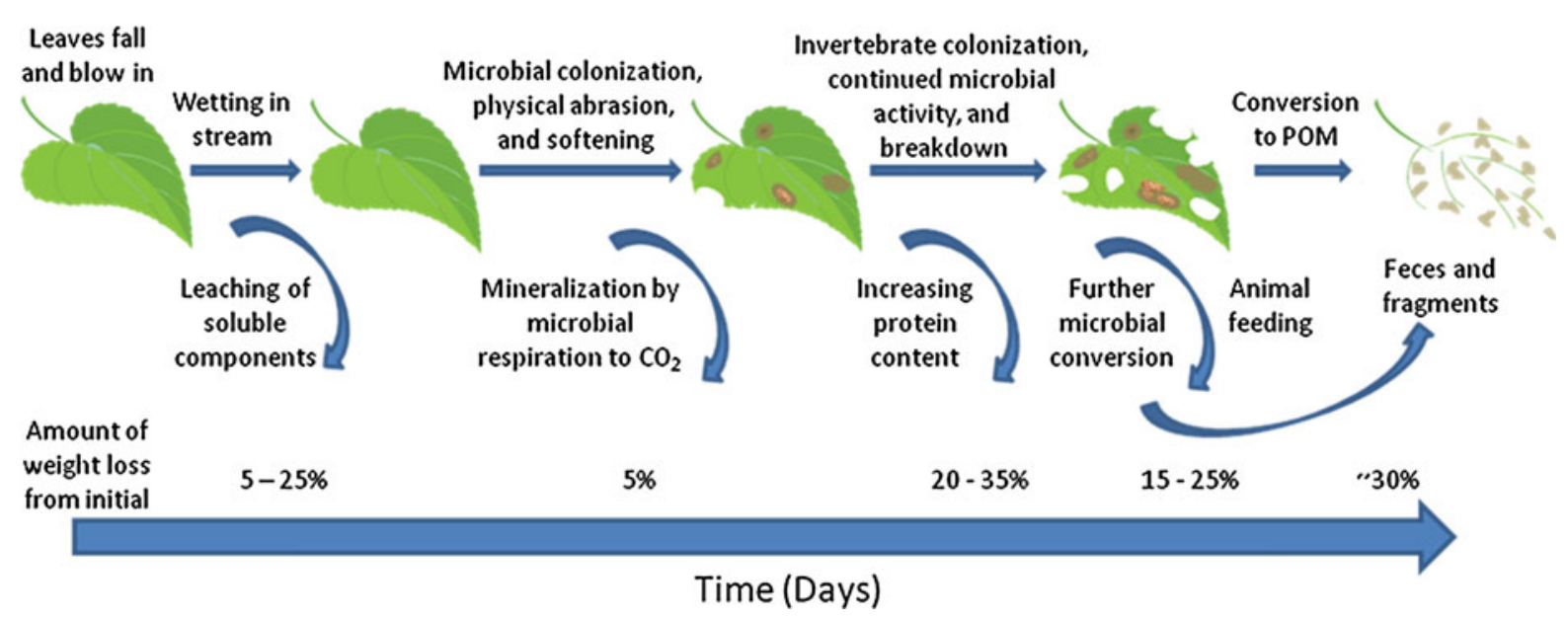

Fig. 1 Leaf breakdown process in natural streams (adapted from Allan and Castillo 2007)

process since it determines the availability of food resources that support large and complex food webs in aquatic and terrestrial ecosystems (Wallace et al. 1997; Chen and Wise 1999; Ponsard et al. 2000; Levin et al. 2001). This process is mediated by a suite of abiotic (e.g., nutrient content, flow of water) and biotic factors (e.g., microbial enzymes, invertebrate feeding) (Webster and Benfield 1986). Macroinvertebrates in aquatic environments often use vegetation debris as a food source (Cummins et al. 1989; Delong and Brusven 1998; Stone et al. 2005), thus crop debris serves as an important source of allochthonous energy and nutrients for biota in agricultural aquatic systems. Bacteria, fungi, and various micro- and macroinvertebrates that consume organic matter/crop debris are themselves consumed by larger organisms, comprising a vital link between detritus and higher trophic levels (Smith 1992).

Once organic matter is colonized by microbes, shredders directly consume the detritus and leaf litter (Cummins et al. 1989; Gregory et al. 1991). Small particles such as pollen and partially digested leaf litter [particulate organic matter (POM)] are available for secondary consumers, herein referred to as particle feeders (also known as collector-gatherers or filterfeeders) (Cummins and Klug 1979; Dieterich et al. 1997; Usio and Townsend 2001). Predators, such as other invertebrates and fish, feed on both types of consumers. Studies in forest streams have revealed that changes in litter inputs have significant in-stream consequences for ecological processes and biota
(Cummins et al. 1989). Thus, changes in terrestrial inputs following human-induced disturbances have the potential to perturb the in-stream food web processes that provide these valuable ecosystem services. In agricultural landscapes, inputs may include increased nutrient concentrations, conventional pesticides, eroded soil, and crop biomass, each of which has the potential to impact ecosystem services (e.g., Pieterse et al. 2003). Acknowledging the risk associated with conventional agricultural practices helps put potential risk associated with GM crops into context within the agroecosystem.

\section{Protection goals}

Protection goals are ecological entities and ecosystem services that are to be protected, as identified by existing regulatory frameworks. As illustrated in Table 1, in most jurisdictions the protection goals are broadly defined, and therefore need to be refined by identifying assessment endpoints (i.e., an explicit expression of the environmental value that is to be protected) and the related measurement endpoints (Sanvido et al. 2011; Wolt et al. 2010). For example, protection of populations of endangered species and beneficial insects (e.g., pollinators or natural enemies) are often listed as assessment endpoints in terrestrial systems because of their value from a biodiversity and ecosystem function viewpoint, respectively. Ultimately, conceptual models need to be constructed on how the GM crop could harm those assessment 
Table 1 Example objectives of relevant biosafety acts or regulations in respect to protection of the environment

\begin{tabular}{|c|c|c|}
\hline Jurisdiction & Objective & References \\
\hline $\begin{array}{l}\text { Cartagena } \\
\text { Protocol on } \\
\text { Biosafety }\end{array}$ & $\begin{array}{l}\text { The objective of risk assessment, under this protocol, is to identify and } \\
\text { evaluate the potential adverse effects of living modified organisms on } \\
\text { the conservation and sustainable use of biological diversity in the likely } \\
\text { potential receiving environment, taking also into account risks to human } \\
\text { health }\end{array}$ & SCBD (2000) \\
\hline Australia & $\begin{array}{l}\text { The object of this act is to protect the health and safety of people, and to } \\
\text { protect the environment, by identifying risks posed by or as a result of } \\
\text { gene technology, and by managing those risks through regulating certain } \\
\text { dealings with GMOs }\end{array}$ & OLD (2000) \\
\hline European Union & $\begin{array}{l}\text { To identify and evaluate potential adverse effects of the GMO, direct or } \\
\text { indirect, immediate or delayed, on human health and the environment } \\
\text { which the deliberate release or the placing on the market of GMOs may } \\
\text { have }\end{array}$ & EC (2001) \\
\hline New Zealand & $\begin{array}{l}\text { To protect the environment, and the health and safety of people and } \\
\text { communities, by preventing or managing the adverse effects of } \\
\text { hazardous substances and new organisms }\end{array}$ & HSNO (1996) \\
\hline \multirow[t]{3}{*}{$\begin{array}{l}\text { United States of } \\
\text { America }\end{array}$} & $\begin{array}{l}\text { To protect "against any unreasonable adverse effects on the environment" } \\
\text {.. "taking into account the economic, social, and environmental costs } \\
\text { and benefits of the use of any pesticide" (which includes GM crops } \\
\text { producing a pesticidal substance) }\end{array}$ & $\begin{array}{l}\text { US Federal Insecticide, Fungicide, } \\
\text { and Rodenticide Act (2004) }\end{array}$ \\
\hline & $\begin{array}{l}\text { To protect and promote the recovery of "endangered and threatened } \\
\text { species and the ecosystems on which they depend..." }\end{array}$ & $\begin{array}{l}\text { US Endangered Species } \\
\text { Act (1973) }\end{array}$ \\
\hline & $\begin{array}{l}\text { Specific to US EPA: To ensure that the use of pesticides [including PIPs] } \\
\text { it registers will not result in harm to the species listed as endangered and } \\
\text { threatened by the U.S. Fish and Wildlife Service, or to habitat critical to } \\
\text { those species' survival... by determining that geographically specific } \\
\text { risk mitigation is necessary to protect federally listed threatened or } \\
\text { endangered species or their critical habitat }\end{array}$ & \\
\hline
\end{tabular}

endpoints. This is followed by the identification of risk hypotheses that are subsequently tested. The most efficient way to test the risk hypotheses is by following the well established tiered approach which generally starts with early tier laboratory testing using surrogate species (Raybould 2007; Romeis et al. 2008).

Understanding the broad protection goals for terrestrial and aquatic ecosystems can help to define assessment endpoints for aquatic ecosystems within agricultural landscapes where GM crops are grown. Protection goals for agroecosystems may be relevant to both permanent and semi-permanent water bodies considered to be important from an ecological point of view, e.g., an aquatic system that supports aquatic life providing an ecological function or that serves as a drinking water or recreational source. When considering insecticidal proteins in Bt maize, examples of assessment endpoints may include population densities of shredders, such as larval caddisflies, aquatic beetles, or midges. For aquatic crops, e.g., flooded rice, where the field may be subject to water management practices, including drying out of the field, the protection goal should be set for those off-field aquatic ecosystems into which the fields drain, rather than within the field itself (EC 2003).

\section{Definition of harm}

Another aspect of protection goals is the need to identify the level of an effect that is harmful. An understanding of how GM crops affect populations or communities of NTOs should be considered in the context of the other perturbations existing in agricultural landscapes, such as crop rotations and management practices, so that the risk assessment of the GM crop focuses on direct toxic effects related to the insertion of the transgene. An operational definition of harm is necessary to determine the significance of any 
adverse effects detected during the analysis phase of an ERA, and the context of how those effects may correlate to larger ecosystem impacts should be considered. For example, under the US EPA framework, a threshold of $50 \%$ mortality or a $50 \%$ effect on growth or reproduction has been accepted for early tier studies, because effects that do not surpass this threshold would be unlikely to cause significant population level effects under realistic environmental conditions (Rose 2007). Furthermore, early tier tests are often performed at $10 \times$ the expected environmental concentration, therefore experimental results that do not cross the threshold of 50\% mortality or growth inhibition are deemed unlikely to cause harm. Following the EFSA guidance for GM crops, "limits of concern" are established based on policy goals, literature, and modeling, which trigger higher tiered testing if exceeded (EFSA 2010a, b). In the case of Bt maize, information concerning the specificity of the trait, as well as the magnitude of toxicity and exposure in terrestrial ERAs, can inform the ERA for aquatic systems. Furthermore, working under an established definition of harm allows risk assessors and risk managers to more easily conclude about the likelihood of cultivation of a GM crop resulting in adverse effects on aquatic systems.

Of foremost consideration in the ERA of GM crops and aquatic ecosystems is the potential for exposure. Once exposure routes are identified, appropriate hypotheses can be formulated to determine testing needs for exposure and hazard characterizations. The potential harm to aquatic ecosystems from transgenic crops is related to the toxicity of the insecticidal protein to aquatic NTOs.

\section{Exposure characterization: input of traits from crop biomass into aquatic system}

\section{Description of conceptual model}

As with the tiered approach used for hazard testing, a similar philosophy can be implemented for exposure assessment. Initial exposure models can use relatively simplistic, worst-case assumptions (e.g. no degradation of protein). As more risk assessment data become available, these models can be refined to include mitigating factors; however, proceeding to higher tier exposure refinements may not be necessary if risk is deemed to be low using the worst-case assumptions. The following case study conceptual model and associated discussion of refinements exemplify this tiered approach for exposure assessment.

Characterizing the potential exposure pathways of aquatic organisms to GM crop material and their associated traits (e.g., insecticidal proteins) is an essential step in the risk assessment process. The routes through which GM crop biomass may enter an aquatic ecosystem may vary, depending on the crop, the region in which it is grown, the purpose for which it is grown (e.g., seed vs. fodder maize), crop management practices, as well as the spatial relationship between aquatic and terrestrial environments. For the purposes of this discussion, a conceptual model, using Bt maize as a case study, was developed to aid in exposure characterization as well as to identify significant exposure pathways (Fig. 2). Entry routes are defined as mechanisms by which GM crop biomass or pure insecticidal protein enters an aquatic system, whereas exposure pathways are defined as routes by which organisms are potentially exposed to the insecticidal protein. There are several routes through which GM crop biomass or insecticidal protein can enter an aquatic system from an adjacent agricultural field. Each entry route is largely influenced by human activity, wind, rain and soil runoff events and includes: (1) erosion of soil and adsorbed protein; (2) surface runoff of freely soluble protein; (3) aerial deposition of pollen and crop dust; and (4) movement of plant tissue and/or senescent crop residue (Fig. 2).

\section{Erosion of soil and adsorbed protein and surface runoff of freely soluble protein}

Throughout the season (vegetative, reproductive and post-harvest stages), insecticidal proteins from plant tissue (living or senescent) may bind to soil or enter soil or water following root exudation, root sloughing, or leaching. Both soil-bound and freely soluble proteins may potentially reach aquatic systems following a rain event via erosion of soil and surface runoff, respectively (Fig. 2, delineated by the letter A). An understanding of the fate of the insecticidal proteins in terrestrial systems is thus critical for assessing potential exposure to aquatic organisms. For instance, while Cry proteins may enter the soil through root sloughing, they have been shown to degrade 
Fig. 2 Conceptual model describing routes through which Bt maize tissue or pure $\mathrm{Bt}$ protein can enter aquatic environments and potential pathways through which non-target organisms can be exposed to the stressor of concern. Solid arrow represents a probable pathway; dashed arrow represents pathway through which protein degradation is likely; dot-dashed arrow represents an unlikely pathway of exposure. Letters $(A-E)$ delineate pathways that have been described in detail in the text

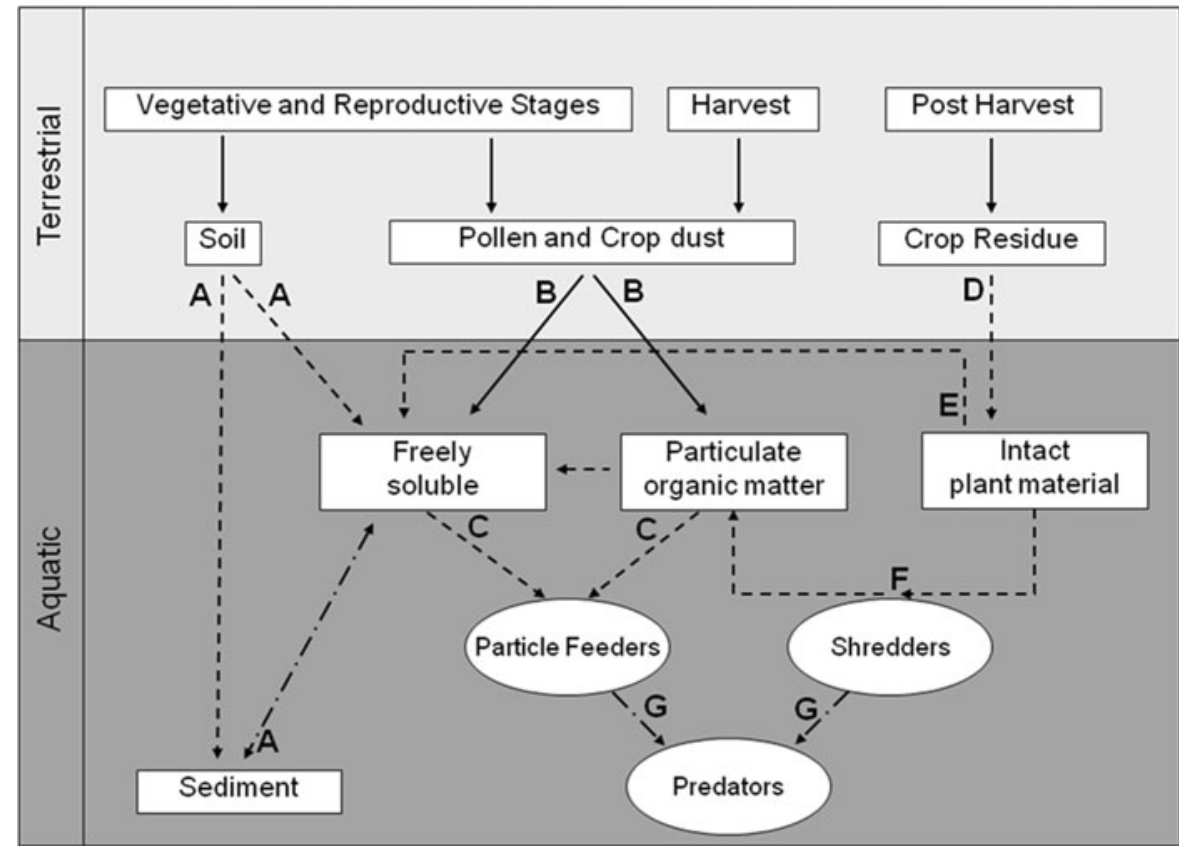

rapidly in soils and bind tightly to soil particles (Head et al. 2002; Icoz and Stotzky 2008; Prihoda and Coats 2008a, b; Clark et al. 2005; Li et al. 2007; Marchetti et al. 2007; Accinelli et al. 2008; Herman et al. 2001; Miethling-Graff et al. 2010; Zurbrügg et al. 2010). From terrestrial fate studies, we conclude that amounts of transgenic proteins entering aquatic systems as a result of root sloughing and soil runoff are extremely low, due to instability in soil (Sims and Holden 1996; Hopkins and Gregorich 2003; Prihoda and Coats 2008b). Furthermore, any insecticidal proteins bound to soils that do enter an aquatic system through runoff will likely remain bound and be part of the sediment (Prihoda and Coats 2008a, b). The route that transports soil-bound $\mathrm{Bt}$ proteins into an aquatic environment therefore represents minimal potential for exposure.

\section{Aerial deposition of pollen and crop dust}

During anthesis and harvest, insecticidal proteins within pollen and crop dust may move off fields via aerial drift. The amount of pollen and crop dust reaching an aquatic system through drift will be limited by the distance from the field, duration of pollen shed and harvest and will vary depending on the prevailing winds, timing of weather events, presence of riparian buffers, and in the case of crop dust, on the type of harvesting equipment used. Therefore quantifying the amount that enters aquatic systems is difficult. Previously, one study estimated annual aerial deposition of $0.1-1.0 \mathrm{~g} / \mathrm{m}^{2}$ of maize pollen into agricultural streams in Indiana (USA) that ranged from 1.7 to $36.3 \mathrm{~m}$ from the corn field border (Rosi-Marshall et al. 2007). Pollen grains entering the water column will lyse and release a portion of their contents into the surrounding water (see supplementary data 3 in Li et al. 2010). Similarly, crop dust may leach freely soluble proteins into the surrounding water column (Li et al. 2007) (Fig. 2, delineated by the letter E). Based on soil fate studies (Sims and Holden 1996; Hopkins and Gregorich 2003; Prihoda and Coats 2008b; Accinelli et al. 2008; Head et al. 2002; Icoz and Stotzky 2007; Clark et al. 2005; Marchetti et al. 2007; Herman et al. 2001), we hypothesize that freely soluble protein is unlikely to be stable in the aquatic environment, however few published studies have tested this hypothesis (Prihoda and Coats 2008a; Tank et al. 2010). Proteins within the pollen capsule or crop dust biomass may also remain within the water column as suspended POM (Fig. 2, delineated by the letter B). They would then represent a potential exposure pathway for aquatic organisms such as particle feeders that feed on POM (Fig. 2, delineated by the letter C). 
Movement of plant tissue and/or senescent crop residue

During the growing season and following harvest, a severe weather event (e.g., heavy rain, wind or hail event) may transport green tissue and/or senescent crop residue (i.e., leaves, stalks and even whole plants) into the aquatic system (Fig. 2, delineated by the letter D). The degree to which GM plant material is translocated from fields to adjacent aquatic systems will vary both temporally and spatially (i.e., throughout a growing season and across different fields). For instance, while pieces of maize leaves may enter the aquatic systems throughout the growing season, input is more likely from post-harvest crop residues (Jensen et al. 2010; Tank et al. 2010). Additionally, the field management practices (e.g., tillage, baling of residue, planting winter cover crops, riparian buffer strips, etc.) as well as the timing of weather events could significantly affect off-field movement of GM plant material. Studies quantifying the movement of intact crop biomass into aquatic environments are limited. In a study conducted in northwestern Indiana, $86 \%$ of streams sampled had maize residue on the stream banks 6 months post-harvest (Tank et al. 2010). Annual inputs of maize biomass (i.e., leaves and stalks) ranging from 0.1 to $7.9 \mathrm{~g}$ ashfree dry mass $/ \mathrm{m}^{2}$ have been reported in twelve agricultural streams in Indiana (Rosi-Marshall et al. 2007). Relatively high inputs of maize leaves were also observed in a low-order (e.g., headwater) stream up to 6 months post-harvest (Jensen et al. 2010). Similarly, maize litter has been observed to comprise greater than $3 \%$ of the total coarse POM, and more than $40 \%$ of the identifiable non-woody organic matter found in streams adjacent to maize fields (Stone et al. 2005).

Once intact crop biomass reaches the aquatic system, freely soluble protein may leach from the crop tissues into the surrounding water column (Fig. 2, delineated by the letter E). Alternatively, intact crop residue may be consumed and broken down into POM by shredders (Fig. 2, delineated by the letter F). In this scenario, shredders may be exposed to $\mathrm{Bt}$ proteins present in the intact plant material; however, the degree of exposure depends on the persistence of bioactive $\mathrm{Bt}$ proteins in the plant tissue.

\section{Tri-trophic food web interactions}

Finally, predators may be exposed to insecticidal proteins through tri-trophic food web interactions (e.g., consumption of exposed particle feeders or shredders) (Fig. 2, delineated by the letter G). Tritrophic transfer of transgenic proteins from prey to predator is relatively well understood in terrestrial arthropod food webs; field studies indicate that the plant-expressed Bt proteins are diluted when moving through the food web (Harwood et al. 2005; Obrist et al. 2006; Meissle and Romeis 2009). Currently, there are no studies that provide evidence that $\mathrm{Bt}$ proteins accumulate in prey tissues, which would result in a more significant route of exposure than via direct exposure to plant material (Romeis et al. 2009). It is to be expected that similar is true for aquatic food webs, negating risk to higher trophic levels.

In summary, the conceptual model describes several routes through which Bt proteins can enter an aquatic system from adjacent agricultural fields, and identifies functional groups of aquatic organisms likely exposed. The process used to develop this conceptual model is appropriate to consider for ERA of future pesticidal GM crops.

\section{Estimated environmental concentrations}

Estimated environmental concentrations (EECs) can be generated for the exposure pathways highlighted in the conceptual model by applying well-established models to produce worst-case (i.e., early tier) exposure estimates. The US EPA farm pond, first described by USDA (1982), is a standard farm pond scenario used for pesticide risk assessment in the USA. The US EPA later refined the model as the "EPA standard agricultural field-farm pond" (also called the "EPA standard pond") to serve as an aquatic model for all aquatic exposure assessments, in which all chemicals could be assessed and compared under the same scenario (Effland et al. 1999). The standard water body was developed to provide an approximation of high-end exposures expected in water bodies, e.g., lakes, and perennial and intermittent streams (US EPA 2000, 2002a). The US EPA standard pond is extremely conservative; the scenario assumes that rainfall onto a treated, 10-hectare (ha) agricultural field causes pesticide-laden runoff into a $20,000 \mathrm{~m}^{3}$ water body ( 1 ha, $2 \mathrm{~m}$ deep). For ecological analyses, the scenario 
Table 2 Worst-case scenario assumptions for the inputs of freely soluble protein, POM, and intact plant material using two models (US EPA standard pond model and EU ditch model)

\begin{tabular}{|c|c|c|}
\hline & US EPA standard pond model & EU ditch model \\
\hline Assumptions & $\begin{array}{l}\text { All plant material from a } 10 \text { ha field drains into a } \\
1 \text { ha pond, } 2 \mathrm{~m} \mathrm{deep}^{\mathrm{a}} \\
0.3 \mathrm{~kg} \text { dry weight/plant }(\mathrm{dw})^{\mathrm{b}} \\
75,000 \text { plants } / \mathrm{ha}^{\mathrm{c}} \\
\text { Bt expression } 2-100 \mathrm{mg} / \mathrm{kg} \text { dry weight plant } \\
\text { tissue }^{\mathrm{d}} \\
\text { Bt expression } 0.02-74 \mathrm{mg} / \mathrm{kg} \text { dry weight pollen }\end{array}$ & $\begin{array}{l}\text { Ditch depth of } 30 \mathrm{~cm}^{\mathrm{e}} \\
100 \mathrm{~g} \text { dry weight } / \mathrm{m}^{2} \text { plant material } \\
\text { deposition }^{\mathrm{f}} \\
\text { Bt expression } 2-100 \mathrm{mg} / \mathrm{kg} \text { dry } \\
\text { weight plant tissue }^{\mathrm{d}} \\
\text { Bt expression } 0.02-74 \mathrm{mg} / \mathrm{kg} \text { dry } \\
\text { weight pollen }^{\mathrm{d}}\end{array}$ \\
\hline $\begin{array}{l}\text { Total Bt protein } \\
\text { calculations }\end{array}$ & $\begin{array}{l}10 \text { ha } * 75,000 \text { plants } / \mathrm{ha}=750,000 \text { maize } \\
\text { plants } \\
750,000 \text { plants } * 0.3 \mathrm{~kg} \mathrm{dw}=225,000 \mathrm{~kg} \mathrm{dw} \\
225,000 \mathrm{~kg} \mathrm{dw} * 2-100 \mathrm{mg} / \\
\mathrm{kg}=450,000-22,500,000 \mathrm{mg} \\
\text { protein }=4.5 \times 10^{8}-225 \times 10^{8} \mu \mathrm{g} \text { total } \\
\text { protein }\end{array}$ & $\begin{array}{l}100 \mathrm{~g} / \mathrm{m}^{2} * 2-100 \mathrm{mg} / \mathrm{kg} \\
\mathrm{dw}=200-10,000 \mu \mathrm{g} \text { total protein }\end{array}$ \\
\hline $\begin{array}{l}\text { Freely soluble protein } \\
\text { (worst-case assumptions) }\end{array}$ & $\begin{array}{l}\text { All protein exists as freely soluble protein } \\
1 \text { ha pond, } 2 \mathrm{~m} \text { deep }=20 \times 10^{6} \mathrm{~L} \\
4.5 \times 10^{8}-225 \times 10^{8} \mu \mathrm{g} \text { protein/ } \\
20 \times 10^{6} \mathrm{~L}=22.5-1,125 \mu \mathrm{g} \text { protein/L }\end{array}$ & $\begin{array}{l}\text { All protein exists as freely soluble } \\
\text { protein } \\
200-10,000 \mu \mathrm{g} \text { protein } / 300 \\
\mathrm{~L}=0.67-33 \mu \mathrm{g} \text { protein } / \mathrm{L}\end{array}$ \\
\hline $\begin{array}{l}\text { Particulate organic matter } \\
\text { (worst-case assumptions) }\end{array}$ & Exposed to $0.02-100 \mathrm{mg} / \mathrm{kg}$ Bt protein & $\begin{array}{l}\text { Exposed to } 0.02-100 \mathrm{mg} / \mathrm{kg} \mathrm{Bt} \\
\text { protein }\end{array}$ \\
\hline $\begin{array}{l}\text { Intact plant material (worst- } \\
\text { case assumptions) }\end{array}$ & Exposed to $2-100 \mathrm{mg} / \mathrm{kg}$ Bt protein & Exposed to $2-100 \mathrm{mg} / \mathrm{kg}$ Bt protein \\
\hline
\end{tabular}

a 20,000,000 L; USDA (1982)

b Nguyen and Jehle (2009); 76,700 kg biomass per hectare divided by 75,000 plants per hectare $=1.02 \mathrm{~kg}$ fresh weight of biomass per plant during the growing season. Assume 70\% moisture; Israelsen et al. (2009)

c 30,000/acre; NASS (2010)

d Nguyen and Jehle (2007, 2009); Raybould et al. (2007)

e $300 \mathrm{~L}$; FOCUS (2003)

f Jensen et al. (2010)

assumes $100 \%$ of the watershed is cropped and treated at the maximum labeled application rate; in addition to runoff, the pond receives drift from the treated area and has no inflow or outflow. Although this standard scenario was designed to predict pesticide concentrations for chemical pesticides, it can also be used for estimating the input of maize biomass into an agricultural water body. Based on US standard farming practices, we assume that approximately 75,000 maize plants are grown per hectare (NASS 2010), and that each maize plant, including all above ground maize biomass weighs approximately $0.3 \mathrm{~kg}$ dry weight (Nguyen and Jehle 2009). Under a worst-case scenario, we assume that all maize biomass from the 10 ha field $[225,000 \mathrm{~kg}$ (dry weight)] will be transported into the pond (Table 2).
In the EU, a static ditch is the standard surface water model under FOCUS steps 1 and 2 for pesticide risk assessment for entry via spray-drift, run-off and drainage (FOCUS 2003). Steps 1 and 2 both use the water body that is a static ditch $30 \mathrm{~cm}$ deep, with a 10:1 field area:water body ratio. For calculating the estimated exposure concentration of freely soluble protein in the ditch via deposition, the only dimension that needs to be considered is depth (Table 2), and the width of the water body is not necessary because of the fixed field:water body ratio (10:1).

Two separate studies have assessed the annual input of maize biomass in agricultural streams. While a study in twelve streams in Indiana, USA reported an input ranging from 0.1 to $7.9 \mathrm{~g}$ ash-free dry mass $/ \mathrm{m}^{2}$ (Rosi-Marshall et al. 2007), data reported for 
Maryland, USA streams ranged from 29.9 to $62.7 \mathrm{~g}$ ash-free dry mass $/ \mathrm{m}^{2}$ (Jensen et al. 2010). Based on these literature values, we make the worst case assumption that $100 \mathrm{~g}$ dry weight $/ \mathrm{m}^{2}$ of maize biomass will enter our model ditch. Using worst-case assumptions, the potential exposure of aquatic organisms to: (1) freely soluble proteins; (2) POM; and (3) intact plant material from GM crops have been characterized using parameters from these two existing models (Table 2), which will help define relevant exposures used in early tier laboratory toxicity studies with NTOs.

\section{Freely soluble protein exposure scenario}

Freely soluble protein may largely be released into the aquatic environment from dispersed pollen, crop dust and intact plant material (senescent and green tissues, Fig. 2). While entry of soil-bound proteins to an aquatic system is possible, the likelihood of those proteins becoming freely soluble in the water column is low and would constitute a very minor exposure pathway (Prihoda and Coats 2008a). Using a worstcase scenario approach, we assume that all maize biomass on the 10 ha surrounding the model pond will enter the pond, and that all insecticidal protein contained in the plant material will leach into the water column and exist as free protein. Similarly, we assume that $100 \mathrm{~g} / \mathrm{m}^{2}$ of maize biomass will enter the model ditch; all protein will leach into the water column and exist as free protein. Making the worstcase assumption that maize biomass contains 2-100 mg Bt protein/kg dry weight tissue (Nguyen and Jehle 2007, 2009; Raybould et al. 2007), that all maize biomass will be transported into the aquatic system at once and that all of the protein within the maize biomass will simultaneously leach into the water column and exist as free protein, aquatic organisms in the pond or ditch would be exposed to a maximum concentration of $22.5-1,125 \mu \mathrm{g} / \mathrm{L}$ or $0.67-33 \mu \mathrm{g} / \mathrm{L}$ of Bt protein, respectively (Table 2 ).

Factors mitigating exposure The above calculations are based on highly unlikely worst-case assumptions. In reality, there are a number of mitigating factors that will reduce the concentration of the freely soluble protein. These include biotic and abiotic degradation of protein, binding to organic matter, and dilution. To date, there have been few studies characterizing aquatic fate (half-life, bioavailability, leaching potential, etc.) of Bt proteins. Previously, Cry3Bb1 maize tissue (stalk, leaf and root) was placed in water/ sediment mesocosms to characterize the fate of the proteins over time (Prihoda and Coats 2008a). Throughout the course of the 30-day study, no proteins were detected in the water or sediment phases. In a separate study by Tank et al. (2010), Cry $1 \mathrm{Ab}$ concentrations in water averaged $0.014 \mu \mathrm{g} / \mathrm{L}$. This suggests either a limited ability of the proteins to leach from intact maize biomass or rapid degradation of leached proteins, both of which would limit exposure of aquatic organisms to freely soluble proteins. Although they are highly unrealistic, these worst-case scenarios have calculated that the EEC of freely soluble protein in these two model systems is in the $\mu \mathrm{g} / \mathrm{L}$ range. Using a similar worst-case approach, Wolt and Peterson (2010) estimated pond concentrations of $1.3 \mu \mathrm{g} / \mathrm{L}$ and wetland concentrations of $7.2 \mu \mathrm{g} / \mathrm{L}$, both of which are comparable to the worst-case concentrations calculated using the EU ditch model. Therefore, in the case of Bt maize, the exposure of aquatic organisms to freely soluble protein is very low (e.g., in the parts per billion range), thereby minimizing risk to particle feeders and fish through gill exposure. Thus, the hypothesis of low risk to aquatic non-target organisms (specifically particle feeders) is sufficiently corroborated due to the very low likelihood of exposure to freely soluble protein, so refinements to early tier exposure estimates are not necessary to evaluate risk in this case. The more likely potential for exposure is to shredders via feeding on intact plant material or particle feeders feeding on POM.

\section{Particulate organic matter exposure scenario}

Particulate organic matter (in the form of pollen, crop dust, and decomposed plant material) may enter aquatic systems and provide a pathway of exposure to aquatic organisms, specifically particle feeders (Fig. 2). Studies measuring the quantity of pollen and crop dust that enters agricultural streams are limited (see "Description of conceptual model") but could be monitored by filtering water and counting granules (Miller and Georgian 1992) or using sophisticated air monitoring equipment. Using a worst-case scenario approach, we assume that the concentration of protein 
within POM is $0.02-100 \mathrm{mg} / \mathrm{kg}$ (Nguyen and Jehle 2007, 2009; Raybould et al. 2007), that the protein in POM does not degrade, and that $100 \%$ of the particle feeders' diet is POM material that comes from $\mathrm{Bt}$ maize. Wolt and Peterson (2010) list a worst-case assumption exposure in maize tissue of $6 \mathrm{mg} / \mathrm{kg}$ and Tank et al. (2010) reported means of $0.1-0.2 \mathrm{mg} / \mathrm{kg}$ in weathered maize tissue 6 months post-harvest. Under these assumptions, particle feeders in both exposure scenarios would be exposed to $0.02-100 \mathrm{mg} / \mathrm{kg} \mathrm{Bt}$ protein in POM.

Factors mitigating exposure The above calculations, based on the US EPA standard pond model and the EU ditch model, assume that the Bt protein is not degraded and remains in bioactive form in the POM. Further, it is assumed that all of the diet of the NTO is POM originating from Bt maize, and that this is the exclusive food source for the organism, as opposed to a choice of other POM or leaf material. If these early tier exposure estimates indicate possible risk based on available hazard data, then refinements may be necessary and further exposure characterization may be useful to understand the relevant exposure concentrations in POM. For instance, there remain gaps in the knowledge surrounding the actual concentration of $\mathrm{Bt}$ proteins that particle-feeding organisms are exposed to, because the fate of $\mathrm{Bt}$ proteins in senescent maize tissue and POM is unknown. Additionally, both the deposition rates for POM from a crop into aquatic environments and the feeding rates of particle feeders on POM are unknown. $\mathrm{Bt}$ proteins in POM are likely to have a short half-life in an aquatic system, due to abiotic and biotic factors (e.g., $\mathrm{pH}$, irreversible binding to sediment particles (Stotzky 2002), increased surface area for microbial activity and subsequent degradation). Insecticidal proteins have been shown to dissipate rapidly in aquatic systems (e.g., Prihoda and Coats 2008a).

When assessing the risks of insecticidal proteins in POM to particle-feeding aquatic organisms, problem formulation is essential for determining realistic exposure. If, after considering mitigating factors during exposure characterization, it is shown that particle feeders receive a significant exposure to insecticidal proteins through POM ingestion, an early tier assay may be recommended for hazard characterization using a suitable surrogate NTO.

\section{Intact plant material exposure scenario}

Green maize tissue and senescent crop residue may enter aquatic systems and provide an exposure pathway to shredders (Fig. 2). Measuring the amount of intact crop biomass (leaves, stalks, cobs, etc.) that enters an aquatic system from an adjacent agricultural field is difficult, and literature values are limited. Previously, litter traps have been placed in streams (Rosi-Marshall et al. 2007) and wire mesh cages have been placed on stream banks (Jensen et al. 2010) to quantify intact biomass inputs. As described previously, these annual inputs ranged from 0.1-7.9 to 29.9-62.7 $\mathrm{g}$ ash-free dry mass $/ \mathrm{m}^{2}$, respectively. Additionally, post-harvest senescent maize residue was identified in 146 of 217 streams sampled in northwestern Indiana 6 months after harvest (Tank et al. 2010).

Using a worst-case scenario approach, we assume that the concentration of protein within the intact plant biomass is $2-100 \mathrm{mg} / \mathrm{kg}$ (Nguyen and Jehle 2007, 2009; Raybould et al. 2007), that all protein is biologically active and that it constitutes all of the shredder's diet. Under these assumptions, shredders in both exposure scenarios are exposed to $2-100 \mathrm{mg} / \mathrm{kg}$ Bt protein in the intact plant material; however, several mitigating factors are likely to reduce exposure levels.

Factors mitigating exposure The above scenario for the US EPA standard pond model and the EU ditch model is based on the assumption that the Bt protein will remain stable over time, and that intact maize material will be the exclusive and preferred food source of organisms. There are a number of mitigating factors which will reduce the amount of traitcontaining intact plant material reaching the pond or ditch, and subsequently serving as a food source, including: (A) land management practices; (B) timing of inputs; (C) nutrient quality and microbial conditioning of plant material; (D) bioavailability of plant proteins; and $(\mathrm{E})$ expression and stability of $\mathrm{Bt}$ proteins.

\section{(A) Management practices}

A variety of land management practices will influence the amount of crop residue left on fields after harvest, as well as the amount of intact plant 
material that is transported off fields (via wind, rain and other weather events). Some land management practices may increase potential biomass inputs into aquatic systems, while others may decrease these inputs. For example, crop cultivation practices (till vs. no-till) may modify opportunities for crop residue movement. The proportion of agricultural fields in the United States that are cultivated using no-till practices is steadily increasing (NRC 2010). While no-till practices help to decrease soil erosion, they allow for increased amounts of crop residues to be left on field surfaces following harvest and thus potentially disseminate into the aquatic environment. An exposure assessment may therefore consider the proportion of the crops cultivated under no-till practices. Likewise, an exposure assessment also could account for the fact that a significant amount of crop residue may be left on conventionally tilled fields if plowing and other seedbed preparation practices are delayed until the following spring.

Different residue management practices used may increase or decrease the opportunity for crop residue movement. For example, many combines/harvesters are equipped with chopping maize heads to breakdown the standing stubble, and adjustable chopper blades inside to reduce the threshed plant material into smaller pieces. Other conditioning devices include chaff spreaders to evenly distribute the residue. After harvest, many growers also use rotary mowers or flail mowers to shorten tall stubble. All of these residue management practices may increase the amounts of particulates and fine intact plant material available to move into water bodies. On the other hand, crop residue may be baled to be fed to livestock, which could reduce the amount of plant material available to the aquatic ecosystem.

Buffer strips and cover crops both mitigate the amount of crop residue movement into aquatic systems (Johnson and Covich 1997). For conservation purposes, many growers will plant winter cover crops in no-till and conventionally tilled crop fields within a relatively short time after harvest. The planting process (usually drilled), even in no-till situations, partially or completely incorporates some of the crop residue into the soil. The structural diversity of the standing cover crop also is expected to reduce the amount of crop tissue movement. Likewise, wide, tall buffers (e.g., warm-season grasses) at the interface between crop fields and aquatic systems also are expected to decrease crop tissue movement into water bodies. In addition, the US Department of Agriculture conservation programs and scientific evidence regarding water quality and nitrogen removal are encouraging the implementation of conservation buffers adjacent to streams to mitigate agricultural impact on waterways (Mayer et al. 2005).

\section{(B) Timing of inputs}

In a 2-year field study conducted in the United States, Jensen et al. (2010) measured the amount of maize biomass entering adjacent agricultural streams over 6 months post-harvest. Maize tissue entered the stream shortly following harvest, however peak tissue inputs were not observed until the early spring (February and March). Jensen et al. (2010) also reported rapid degradation of $\mathrm{Bt}$ protein in postharvest tissue, as measured by sensitive insect bioassay. Therefore, a delay between harvest and peak tissue input into streams may significantly decrease exposure for many aquatic consumer populations. Accounting for temporal overlap between the maize tissue inputs and aquatic species lifecycles is an important component of the exposure assessment.

(C) Nutrient quality and microbial conditioning of maize tissue

Variation in plant tissue nutrient content, as well as secondary and structural compounds, is known to alter consumer feeding behavior, thus influencing organic matter breakdown (Iversen 1974; Webster and Benfield 1986; Campbell and Fuchshuber 1995). The relatively low nutrient content of senesced maize tissue (Menninger and Palmer 2007) may lead consumers to avoid maize tissue when they have a choice of other organic material on which to feed. Likewise, macroinvertebrate colonization and consumption of decaying plant tissue in the aquatic environment is dependent upon microbial colonization and "conditioning" (Webster and Benfield 1986). Microbial conditioning of plant tissue can increase nutrient availability to macroinvertebrates, but may also decrease the stability of insecticidal protein (Prihoda and Coats 2008a; Jensen et al. 2010). Preference of food items may decrease the proportion of consumer diets that is comprised of maize tissue and microbial conditioning may decrease protein concentrations, both of which would significantly decrease macroinvertebrate exposure to insecticidal proteins, 
relative to the exposure calculated based on worst-case assumptions.

\section{(D) Protein bioavailability}

Numerous studies examining the fate of Bt proteins in terrestrial environments indicate relatively short half-lives and rapid dissipation in soil (e.g., Accinelli et al. 2008; Head et al. 2002; Icoz and Stotzky 2007; Clark et al. 2005; Marchetti et al. 2007; Herman et al. 2001; Prihoda and Coats 2008a, b; Zurbrügg et al. 2010). Similar binding and dissipation in aquatic sediments, may greatly limit the availability of $\mathrm{Bt}$ proteins to aquatic organisms.

\section{(E) Expression and stability of Bt proteins}

Several factors may affect the stability of $\mathrm{Bt}$ proteins in plant tissue following harvest. Proteases, microbial degradation, or abiotic factors $(\mathrm{pH}$, freezethaw cycles, and UV light) may all decrease the concentration of bioactive $\mathrm{Bt}$ proteins to which aquatic organisms are exposed. The decomposition of the plant material itself is an important component of the degradation process and the dissipation of Bt proteins in plant material over time should be accounted for in the exposure assessment. For example, Wolt and Peterson (2010) performed prospective problem formulation in which they accounted for protein degradation over time as a result of abiotic and biotic degradation. These estimations are supported by data presented in a 30-day laboratory study which indicated that the half-life of Cry3Bb1 protein within submerged leaf and stalk tissue (event MON863) was short (less than 3 days) and the potential for Cry3Bb1 proteins to leach from leaf and stalk material was limited (Prihoda and Coats 2008a). Additionally, exposure assessments should be conducted on a trait-by-trait basis, and should consider not only the protein concentrations within different crop tissues (leaf, stalk, pollen, etc.), but also the protein concentrations throughout the growing season (vegetative emergence through senescence). Commercial hybrids of Bt maize may employ different transformation events and different genetic promoters that control the introduced transgenes, and hence express variable amounts of Bt protein. For example, expression of Cry1 $\mathrm{Ab}$ in leaf tissues of different commercial constructs ranged from 2.1 to $225.0 \mu \mathrm{g} / \mathrm{g}$ fresh weight (Dutton et al. 2003). Likewise, during different growth stages of the plant concentrations may vary over time. Additionally, in certain constructs, the highest expression is found in the leaves and/or roots whilst lower amounts of $\mathrm{Bt}$ proteins are found in the pollen or stalks. In the worstcase exposure assessment model, we assume that aquatic organisms are exposed to intact plant material containing a high concentration of Bt protein (i.e., the concentration observed at late reproductive stages of the plant); however, more realistic exposure scenarios would account for differences in Bt protein concentrations in different plant tissues and in post-harvest tissues. Wolt and Peterson (2010) estimated maize tissue concentrations of $6 \mathrm{ng} / \mathrm{mg}$ using worst-case assumptions, while Tank et al. (2010) measured $\mathrm{Cry} 1 \mathrm{Ab}$ in in-stream maize residue and reported concentrations of 0.1 and $0.2 \mathrm{ng} / \mathrm{mg}$, orders of magnitude below Wolt and Peterson (2010) and those reported here.

As with EECs for POM, if early tier worst-case exposure estimates indicate possible risk based on available hazard data for sensitive insects, then refinements to the exposure characterization may be necessary. These refinements may include further characterization of the amount of crop material that enters an aquatic system, as well as the environmental fate of the insecticidal protein. If, after considering mitigating factors, it is shown that shredders receive a significant exposure to insecticidal proteins through ingestion, an early tier assay may be recommended for hazard characterization using a suitable surrogate NTO to adequately assess risk.

In summary, early tier EECs were generated using the conceptual model, worst-case assumptions, and available models and data. The case study conceptual model was used to identify pathways through which aquatic organisms may be exposed to insecticidal traits in GM maize tissue. The process used to develop EECs is appropriate for ERA of future pesticidal GM crops. Should refinements to the early tier exposure characterization become necessary, mitigating factors were also detailed. Based on our case study exposure assessment, organisms fulfilling the predator or particle feeder functional groups will likely receive minimal exposure to Bt proteins. Shredders are also expected to receive minimal exposure to Bt proteins, however, based on feeding behavior represent more realistic assessment endpoints for hazard testing, if it is deemed necessary for future products. Due to the variability of protein expression across events, the need for hazard assessment and early-tier toxicity 
testing must be assessed on a case by case basis, following thorough problem formulation and exposure assessment. In the event that exposure assessment demonstrates a low risk, hazard testing may not further inform the risk assessment.

\section{Early tier toxicity testing}

A tiered testing approach for hazard assessment helps inform the ERA (Garcia-Alonso et al. 2006; Rose 2007; Romeis et al. 2008). Early tiers are designed to be conservative to represent worst-case exposure conditions and increase the likelihood of detecting a possible hazard. A margin of exposure is often built in to early tier tests to account for potential interspecies variability in terms of response to the stressor; US EPA for example recommends a margin of exposure of $>10 \times$ the EEC (Rose 2007). Effects detected in such worst-case early tier tests may trigger testing with refined exposure estimates or more realistic margins of exposure (i.e., $1 \times$ the EEC). On the other hand, if no adverse effects are detected in early tier testing using the worst-case margin of exposure, it can be concluded that at realistic environmental concentrations the risk to NTOs would be negligible.

For early tier laboratory testing protocols to be reconstructable, interpretable, and reliable, the tests need to be standardized and fulfill certain quality criteria, which are discussed by Romeis et al. (2011). These criteria include test substance characterization and equivalence, test substance stability and homogeneity, experimental design, determination of exposure concentrations (nominal vs. measured), plant tissue selection, and selection of a suite of non-Bt hybrids for appropriate controls to overcome potential nutrient differences among hybrids (Romeis et al. 2011). Considerations for experimental design in aquatic studies depend on the choice of test substance delivery. For protein-based studies, desorption of the protein from the diet should be characterized. When plant material is used, conditioning of plant material by microbial communities must be considered as it is often a requirement for test organism acceptability of a food source. An understanding of how microbial conditioning affects the stability of the protein within the plant tissue will also be important. If degradation of the Bt protein is substantial, the early tier aquatic assay may not be warranted due to negligible exposure, thereby negating risk. In either case, appropriate characterization of diet should include a sensitive insect bioassay with a validated limit of detection to evaluate biological activity, and validated ELISA methodology that has taken into consideration spike/ recovery, matrix effects, dilution agreement, etc. Use of a validated ELISA for fully characterizing the diet (e.g., dose, stability, homogeneity) should be paired with a validated sensitive insect bioassay, since in some cases the concentration of protein detected by the ELISA does not correlate with bioactivity of the protein. Many of the previously published studies examining the potential hazard of GM plant tissues or protein-based artificial diets have failed to adequately validate the ELISA and have failed to provide evidence of biological activity of the protein (e.g., Tank et al. 2010; Rosi-Marshall et al. 2007). Lack of these controls and validation steps makes interpretation of results difficult, and potentially produces confounding artifacts that are difficult to discern. Therefore, these study design considerations are important and should be included in high quality early tier tests (Romeis et al. 2011).

With the understanding that not every species can be tested in an early tier test, it is important to recognize the utility of the surrogate species concept, which is widely used in ecology, toxicological testing, and risk assessment (e.g., Banks et al. 2010; Caro and O'Doherty 1999; Favreau et al. 2006). Surrogates are those species deemed similar in several ways to species of concern (i.e., those of value for conservation) and are used to experimentally predict how disturbances may impact those species. Species selected for laboratory toxicity studies fulfill the following criteria:

- Likely to be sensitive due to phylogenetic relatedness to the target pest, with the assumption that physiology is shared among close relatives.

- Indigenous to the ecosystem and/or representatives of species that have ecological, commercial or recreational importance.

- Widely and readily available; techniques for culturing are established, a commercial supply is available.

- Amenable to testing under laboratory conditions, preferably with an available standardized test method. 
- Well-characterized with respect to their life histories to facilitate endpoint selection and interpretation of test results.

Standardized early tier testing protocols for insecticidal GM crops are relatively well developed for terrestrial organisms in comparison to aquatic organisms. For terrestrial NTOs, each surrogate species used in early tier tests is chosen to represent organisms to which it is taxonomically related, organisms to which it is functionally similar, or both. Since aquatic NTOs may be taxonomically or functionally related to terrestrial organisms, results from tests with terrestrial NTOs may be equally representative for aquatic NTOs. However, in addition to data retrieved from terrestrial NTOs, surrogates of aquatic species may be tested if it is deemed necessary from problem formulation and exposure assessment (i.e. the exposure profile or taxonomy differs significantly between the terrestrial and aquatic species). An understanding of the ecology of aquatic ecosystems is thus critical for determining relevant species for early tier toxicity testing.

Possible surrogate test species for early tier laboratory studies

Considering the receiving environment, e.g. streams, ponds, ephemeral wetlands in agricultural regions, the following groups of aquatic organisms were initially considered: Amphipoda, Cladocera, Isopoda, Coleoptera, Diptera, Lepidoptera, Ephemeroptera, Trichoptera, Oligochaeta, Gastropoda, and Plecoptera (Table 3). As previously described, for a Bt maize case study, aquatic organisms are most likely to be exposed to insecticidal proteins via intact plant material; organisms feeding on intact plant material would belong to the shredder functional group. Most common groups of shredders in temperate regions include crustaceans (e.g., Isopoda and Amphipoda), Plecoptera, Trichoptera (especially Limnephilidae), and Diptera (Cummins et al. 1989). Stream-inhabiting lepidopterans feed on algae on rocks, thus are unlikely to encounter transgenic insecticidal proteins in their food (Solis 2008). Most coleopterans in streams are not shredders of decaying vegetation, with the exception of selected species of Ptilodactylidae and perhaps Hydrophilidae, and these generally feed on decaying wood
(White and Roughley 2008). Furthermore, Coleoptera and Lepidoptera are included in the terrestrial risk assessment, and were therefore not considered as relevant aquatic test species. Based on the mechanism of feeding, a list of possibly exposed organisms was constructed (Table 3). The list was narrowed based on the species selection criteria outlined above, e.g., species with no available culturing or testing methods were eliminated from the list. The narrowing process is described below.

\section{Crustacea}

Amphipoda: Hyalellidae The amphipod, Hyalella azteca, is an epibenthic shredder that is found in a variety of static and moving freshwater and estuarine habitats throughout North America, Central America, and the Caribbean Islands (Lowry 2010). H. azteca reproduces sexually and is able to tolerate a wide range of environmental conditions. Due to its long history of use in aquatic toxicity testing, optimal conditions for culturing and testing have been documented in the literature (US EPA 2000; ASTM 2008a). A large amount of data exists on this species, which can serve as a baseline for comparative toxicity studies. H. azteca is known to feed upon bacteria, algae and non-living organic detritus (e.g., leaf material) (Hargrave 1970). As such, conditioning of fresh plant material may be required before use in a H. azteca feeding study. In the laboratory, amphipods can be reared on either a natural (leaf tissue, algae) or artificial (commercial fish flake food) diet. Though a crustacean and likely not susceptible to current insecticidal traits within GM crops that target certain insect orders, this species may prove to be a useful test system for future GM crops.

Cladocera: Daphniidae Daphnia magna and Ceriodaphnia dubia have a long history of use for chemical toxicity testing on aquatic organisms, and have been used previously for early tier testing for GM crops. Standardized guidelines exist for chemical toxicity testing and rearing (OECD 2004b; US EPA 2000; ASTM 2008a). D. magna is distributed worldwide in the northern hemisphere. It is absent from Alaska and the eastern US, with the exception of northern New England. Daphnia pulex occurs in most of North America and likely occurs in Europe and South America. D. pulex is principally found in ponds, 


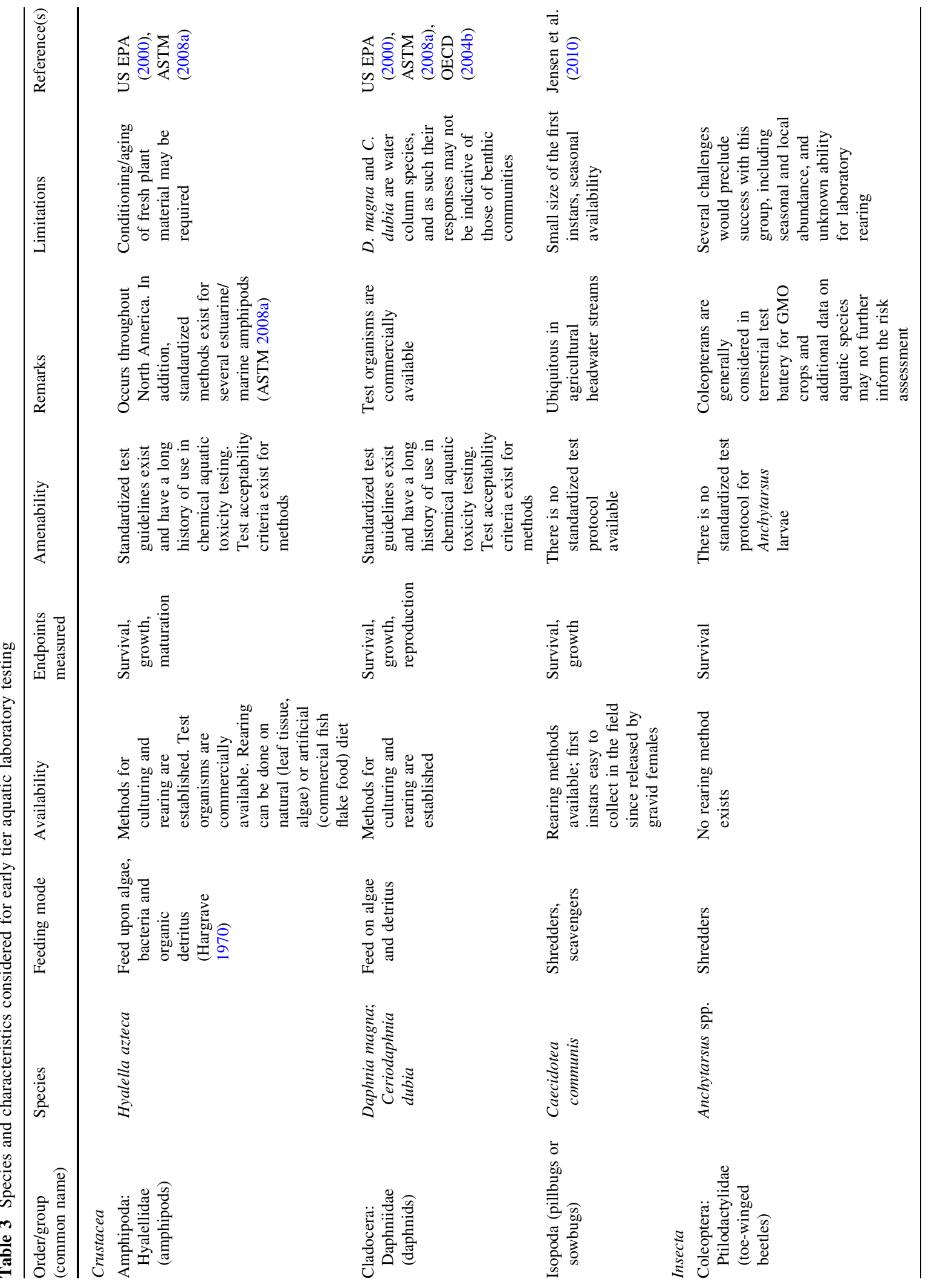




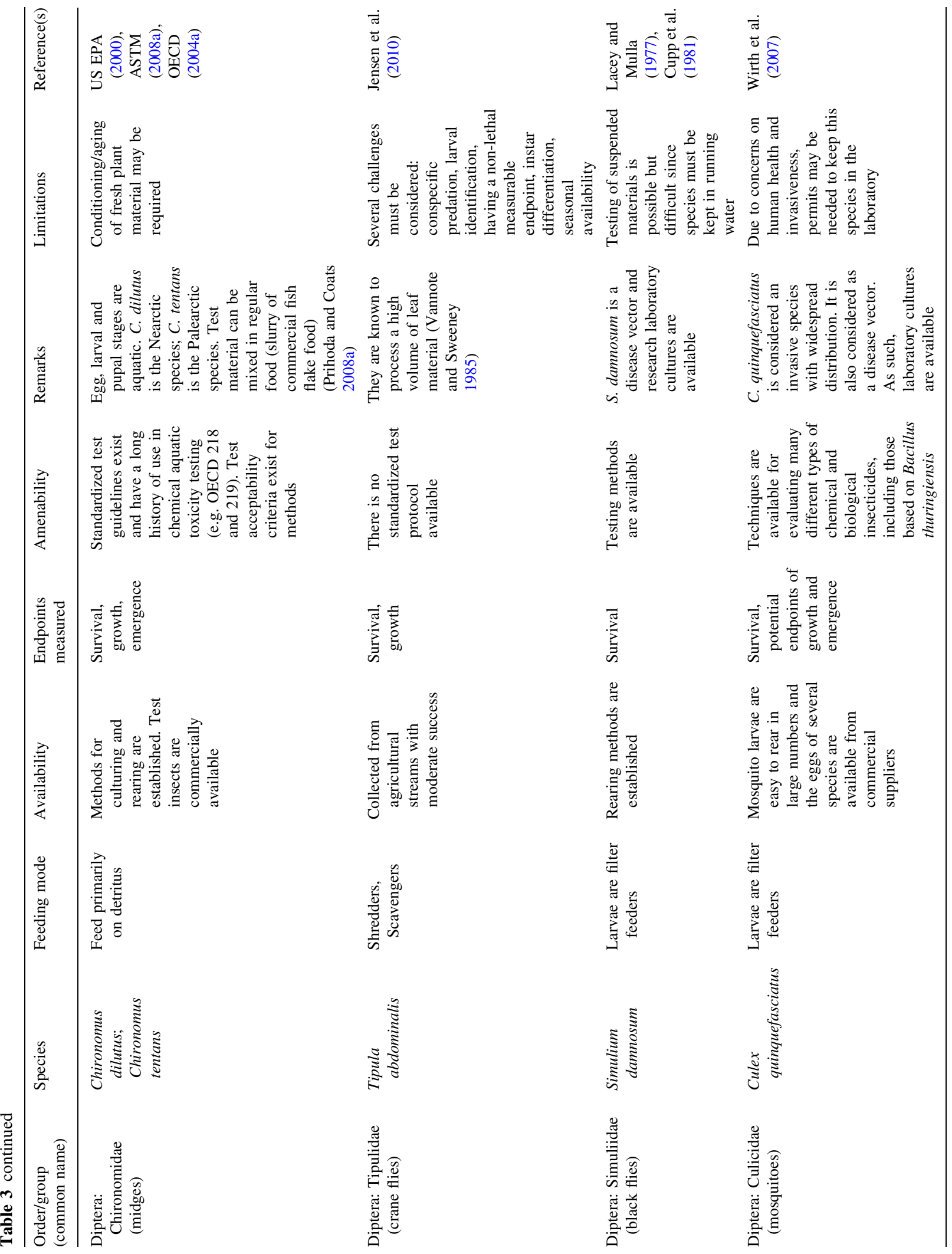




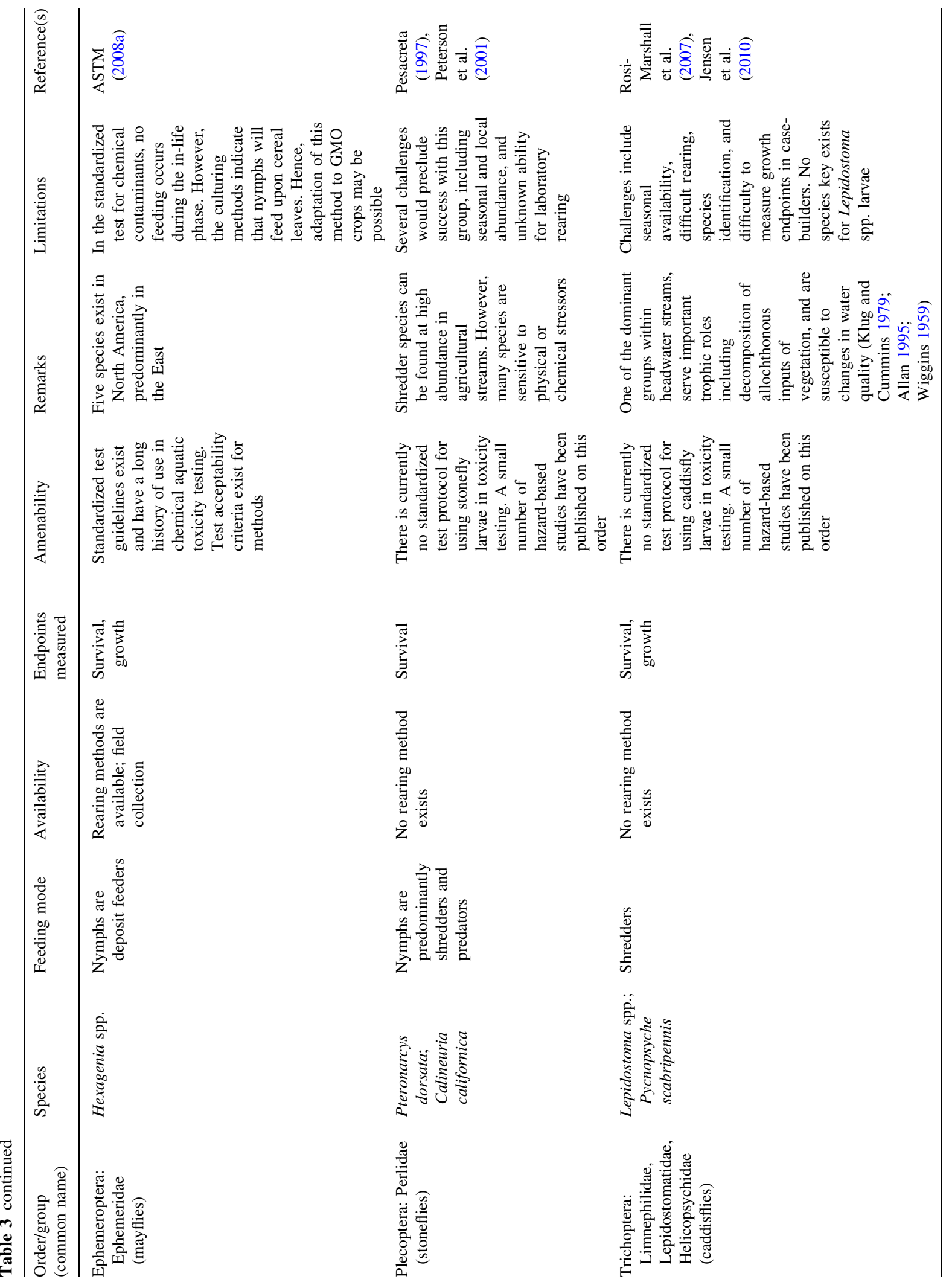




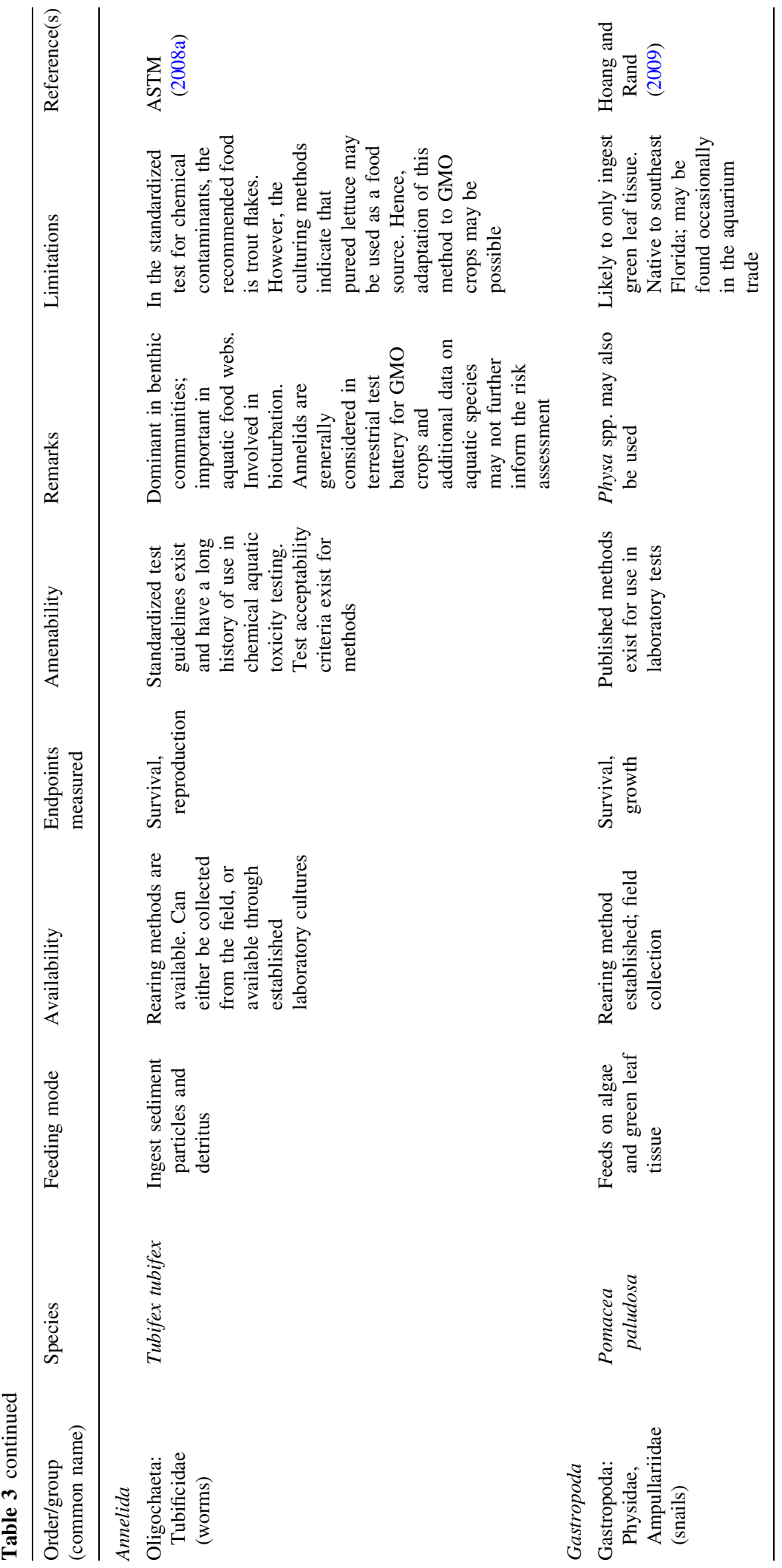


whereas $D$. magna is generally a lake dweller; both species occupy lentic habitats (US EPA 2002b). C. dubia is a littoral species found in lentic habitats with a worldwide distribution and is most often associated with aquatic vegetation (US EPA 2002b). These organisms are primarily particle feeders found within the water column and as such they may not be representative of benthic or epibenthic communities. All three species of daphnids mentioned herein are available from commercial suppliers. As a welldocumented surrogate species and a member of a taxonomic group not typically tested for terrestrial ERA, daphnids have previously been tested in the hazard assessment of GM crops and have helped to inform the risk assessment by defining spectrum of activity. However, based on exposure characterization, there is limited evidence to suggest that D. magna or other particle-feeding organisms are exposed to significant levels of Bt proteins via POM in the water column; therefore, daphnia may not make sense to test for all traits. The decision to including an early tier daphnid assay should be in specific cases (e.g., insecticidal compounds with broad spectrum of activity), and when problem formulation deems it relevant for informing the risk assessment.

Isopoda: Asellidae Aquatic isopods are common shredders in both lotic and lentic systems around the world. They are relatively easy to rear in the laboratory, and collection of first instars is relatively simple as they are released by gravid females. Jensen et al. (2010) used Caecidotea communis, due to its ubiquity and high numbers in agricultural headwater streams in Maryland; C. communis is distributed across temperate North America in small streams (Williams 1972; GBIF 2011). There is no commercially available source, nor standardized test protocol for using aquatic isopods in toxicity testing, and challenges in lab testing include small size of early instars and seasonal availability.

\section{Insecta}

Coleoptera: Ptilodactylidae Aquatic beetle larvae in the genus Anchytarsus are epibenthic shredders that could potentially serve as a test species for early tier testing. Most species from the Ptilodactylidae are found in the tropics, but some are also found in the eastern USA, with few representatives in the west and
Canada (Arnett et al. 2002). Coleoptera are often included in the ERA for terrestrial organisms since this taxonomic order contains many species valued for biological control (OECD 2007; Rauschen et al. 2010). Data from terrestrial ERA may be used to inform the risk assessment of aquatic coleopterans, therefore additional early tier testing with aquatic species may be redundant. Furthermore, there are several major factors limiting the feasibility of early tier testing for aquatic Coleoptera, including lack of established laboratory rearing methods, seasonal and local abundance, and lack of standardized test protocol for Anchytarsus larvae.

Diptera: Chironomidae The genus Chironomus is comprised of insects, which have aquatic egg, larval and pupal stages. Two primary species are used in aquatic toxicity testing: $C$. dilutus (formerly $C$. tentans) which has a Nearctic distribution, and $C$. tentans, which is found in palearctic regions. Larval $C$. dilutus are epibenthic species commonly found burrowing within the top few centimeters of sediment in lotic and lentic freshwater habitats. Immature chironomids are known to feed primarily on detritus and often ingest sediment simultaneously due to their varied feeding behaviors (shredders, particle feeders) (Pinder 1986). Within the laboratory, $C$. dilutus larvae are fed a slurry of commercial fish flake food. The long history of use of C. dilutus in aquatic toxicity testing has provided robust methods for culture, testing and response comparison (US EPA 2000; ASTM 2008a; OECD 2004a). As an insect (with an alkaline gut), C. dilutus larvae are a relevant test organism for aquatic studies with $\mathrm{Bt}$ proteins. This species can be cultured and tested using natural or formulated sediments, or a sand substrate. For testing with insecticidal GM crop material, $C$. dilutus can be fed via plant materials homogenized within the slurry diet (Prihoda and Coats 2008a) or mixed within the formulated substrate.

Diptera: Tipulidae Cranefly larvae are common shredders most often found in lentic-littoral and lotic-erosional epibenthic habitats around the world (Byers and Gelhaus 2008). They are common in loworder streams and are known to process a high volume of leaf material (Vannote and Sweeney 1985), both of which are desirable characteristics for a surrogate test species. However, several factors limit the feasibility for early tier testing, including lack of commercially 
available source, lack of standardized test protocol for using cranefly larvae in toxicity testing, and several other challenges, e.g., conspecific predation, larval identification, lack of a non-lethal measurable endpoint, instar differentiation, and seasonal availability. Jensen et al. (2010) used Tipula abdominalis collected from an agricultural stream in Maryland with moderate success.

Diptera: Culicidae and Simuliidae The immature stages of mosquitoes (Culicidae) and blackflies (Simuliidae) are widely distributed particle feeders that rapidly remove POM suspended in water, providing a potential route of exposure should POM be identified as a major route. Mosquito larvae are typically found in static water bodies, are easy to rear in large numbers, and the eggs of several species are available from commercial suppliers. Standard techniques are available for evaluating many different types of chemical and biological insecticides, including those based on Bt. For example, Wirth et al. (2007) utilized Culex quinquefasciatus (Culicidae) larvae to investigate the effects of Bacillus sphaericus and Cry11A. Blackfly larvae also can be reared for testing non-target effects, but with more difficulty, as they must be reared in running water to test suspended materials. Existing bioassays for mosquito larvae and even for blackflies, could be modified for evaluating materials such as pollen and decomposing leaf litter particulates from insecticidal GM crops (e.g., Wirth et al. 2007; Lacey and Mulla 1977; Cupp et al. 1981). However, based on their feeding mechanisms (filtering), these organisms may not represent the shredder group as adequately as other Dipterans, such as chironomids.

Ephemeroptera: Ephemeridae In the case of mayflies, Hexagenia spp. nymphs are benthic particle feeders and live in u-shaped tubes in the sediment of lentic and lotic systems throughout North America (Waltz and Burian 2008). Standardized guidelines exist for the use of nymphs of Hexagenia spp. for aquatic toxicity testing (ASTM 2008a). The most common test species are $H$. limbata, $H$. rigida, $H$. bilineata, and $H$. munda. As these organisms require field collection, their geographical and temporal limits may influence their applicability as a test organism. In addition, the guidelines presented by ASTM (2008a) are designed for the testing of chemical contaminants and no feeding occurs during the in-life phase of the study. However, the culturing methods do recommend that Hexagenia nymphs may be fed cereal leaves. As such, adaptation of this method for use with GM crop leaf tissue may be possible, but no methods or commercial supply are currently available.

Plecoptera: Perlidae Stonefly nymphs can be numerous in headwater streams and are predominantly within shredder and predator functional niches (Delong and Brusven 1998). Pteronarcys dorsata is one of the most common stoneflies in the eastern US and commonly used for ecological experiments (Pesacreta 1997) and Calineuria californica has been used to measure pesticide toxicity in the laboratory (Peterson et al. 2001). Despite their presence in headwater streams and sporadic use in preliminary hazard studies, there remains no standardized test protocol for using stonefly nymphs in toxicity testing. Challenges to meaningful bioassays using stoneflies include seasonal and local availability, lack of a commercially available supply, and the development of rearing protocols.

Trichoptera: Limnephilidae, Lepidostomatidae, and Helicopsychidae Caddisfly larvae are one of the dominant groups within headwater streams around the world, fill an important functional niche for the decomposition of allochthonous vegetation in the epibenthic habitat, and are susceptible to changes in water quality (Cummins and Klug 1979; Allan and Castillo 2007; Wiggins 1959). Net-spinning caddisflies selectively ingest POM accumulated on silken nets (Georgian and Wallace 1981; Alstad 1987). Animal tissues, detritus and algae primarily contribute to netspinning caddisfly diets, however the relative contributions of each category will likely vary based on species preferences (Benke and Wallace 1980; Merritt et al. 2008). Case-building caddisflies employ nearly every functional feeding strategy within aquatic habitats, with shredders, grazers, scrapers, piercers, predators, and particle feeders all represented within the various families (Merritt et al. 2008). Case-builders appear to show similar selectivity in those resources actually ingested, with little evidence of inorganic material composing a part of their gut contents (Mecom 1972; Becker 1994). Of those listed above, shredders and particle feeders would have the greatest potential exposure to agriculturally related inputs. 
A small number of hazard-based studies with GM maize have been published on caddisflies. Jensen et al. (2010) measured the growth of two field-collected trichopteran shredder species, i.e., Pycnopsyche cf. scabripennis (Limnephilidae) and Lepidostoma spp. (Lepidostomatidae) fed conditioned maize tissue. Rosi-Marshall et al. (2007) fed field-collected Lepidostoma liba (Lepidostomatidae), for 29 days on conditioned maize litter collected from field sites. Rosi-Marshall et al. (2007) also tested a trichopteran algal scraper, Helicopsyche borealis (Helicopsychidae), reared in aerated groundwater inoculated with algae and supplemented with maize pollen treatments. Despite these few preliminary hazard studies, there remains no standardized test protocol for using caddisfly larvae in toxicity testing, and many challenges surrounding this order include seasonal availability, lack of commercially available supply, difficulty with rearing, species identification, and difficulty in measuring growth endpoints for case-builder species. These challenges must be overcome before meaningful bioassays for ERA of insecticidal GM crops can be implemented. Furthermore, such assays should only be triggered by problem formulation, e.g., such tests may be informative in a case of Lepidoptera-active traits due to the close taxonomic relationship between Lepidoptera and Trichoptera. However, in such a case data available from the terrestrial ERA may be more useful than implementation of a new Trichoptera bioassay, i.e. it may be more appropriate to assume some level of sensitivity based on a range of sensitive terrestrial Lepidoptera species, as was done by Wolt and Peterson (2010), and Wolt et al. (2005).

\section{Annelida}

Oligochaeta: Tubificidae Globally, particle-feeding tubificids are a major component of the benthos of freshwater and estuarine sediments in both lentic and lotic habitats (ASTM 2008b). The oligochaete worm Tubifex tubifex has been used extensively in aquatic toxicity testing, and standardized guidelines are available (ASTM 2008a). They are commercially available from aquatic toxicology research suppliers and through the aquarium trade. However, like Coleoptera, annelids are generally considered in the terrestrial ERA for insecticidal GM crops. Hence, additional early tier testing on an aquatic species may not further inform the aquatic risk assessment.

\section{Gastropoda}

Physidae and Ampullariidae Freshwater gastropods have been used in aquatic toxicity testing. For instance, the freshwater pulmonate snail, Physa spp. (Physidae) has been used in aquatic toxicity testing with chemicals for decades (Arthur and Leonard 1970). Physa spp. are epibenthic/epiphytic and feed by scraping diatoms, algae, and detritus from submerged surfaces in lentic waters and by grazing on aquatic macrophytes. They are native to Europe, North and Middle America and western Africa (ASTM 2008b). Likewise, the apple snail, Pomacea paludosa (Ampullariidae) is amenable to laboratory rearing and published methods exist on its use in laboratory tests (Hoang and Rand 2009). World-wide, apple snails inhabit tropical and subtropical wetland (lentic) epibenthic and epiphytic habitats; the range of $P$. paludosa (the only continental US apple snail) in the USA encompasses the Florida peninsula (Thompson 1984). Apple snails feed by scraping algae and green leaf tissue and could serve as a surrogate species for aquatic testing with GM crops if methods are refined. Gastropods are likely not susceptible to current traits within GM crops that target certain insect orders; however this species may prove to be a useful test system for future GM crops. $P$. paludosa are not commercially available, but take easily to laboratory culture. Other Pomacea species are available through the aquarium trade.

Following the species selection criteria outlined previously, the amphipod, H. azteca, and the chironomid, $C$. dilutus, were determined to be the most suitable aquatic surrogate species for extending the range of organisms available for effects tests for aquatic ERA. Decisions to test one or both of these shredder species instead of species currently used will depend on the analysis plan developed from the conceptual model, as well as changing regulatory requirements. Currently, the major limitations for working with species belonging to Isopoda, Oligochaeta, Coleoptera, Diptera (Tipulidae), Plecoptera and Trichoptera include the lack of a commercially available supply and lack of standardized testing protocols. For Gastropoda and Diptera (Culicidae and Simuliidae) published methods are available, but there are presently no standardized testing protocols available. Given the current aforementioned limitations, 
significant improvements in culture availability, rearing and test method development would be required for reliable use in early tier testing for regulatory purposes. In contrast, testing guidelines have been established by the US EPA for freshwater sediment toxicity assays using both $H$. azteca and $C$. dilutus (US EPA 2000) for conventional chemical pesticides. These organisms have a long history of use in chemical aquatic toxicity testing, and current guidelines, including both lethal and sub-lethal endpoints. Both species have been used successfully in wateronly and sediment tests with chemical toxicants, and their responses in the laboratory have been shown to be representative of those of natural benthic populations (US EPA 2000). Standard methods are available for 10-day short-term toxicity tests for each species with measured endpoints of survival and growth (length, weight). Additionally, long-term test methods (42 days for H. azteca and 60 days for C. dilutus), that include a reproduction endpoint are available should problem formulation and early tier testing indicate a need for higher tiered testing. In cases where exposure through particle feeding is identified as a potentially major route, testing with daphnids may also be considered. Testing protocols for short-term aquatic toxicity testing with Daphniidae are widely used (OECD 2004b; US EPA 2000; ASTM 2008a). While these testing guidelines are based on conventional chemical pesticides, a long history of using these organisms has been established and these methods and test endpoints can provide a baseline of testing guidance for assessing toxicity of GM crops to aquatic organisms as well.

Furthermore, considering the selection criteria, shredders like $H$. azteca are most likely to be exposed based on manner of feeding, and they represent realistic candidate species for early tier testing of insecticidal GM crops. Dipterans are also known to have alkaline gut conditions, comparable to some target insect pests, therefore chironomids could be similar in a response to a future pesticidal GM crop. Both $H$. azteca and $C$. dilutus are indigenous to the aquatic ecosystem and representative of the shredder functional group, they are commercially available, can be reared in the laboratory, and they have proven to be amenable to testing under laboratory conditions. Likewise, both species have well-characterized life histories, which serve to facilitate interpretation of early tier test results. Based on the selection criteria and characteristics of the species, H. azteca and C. dilutus are recommended as potential test organisms for aquatic toxicity testing of GM crops, for products where shredders are likely to be exposed to environmentally significant concentrations.

\section{Conclusions}

To adequately assess risks of GM crops to the environment, both the potential for exposure and hazard are important considerations. If exposure is shown to be low, then overall risk is also likely to be low. Likewise, if toxicity is shown to be low, then overall risk is also likely to be minimal. Thus, in cases where exposure is determined to be very low and/or where the spectrum of activity is narrow and welldefined, a conclusion about risk can be reached with either adequate hazard testing or exposure characterization, as is true for current insecticidal GM crops.

This case study of Bt maize is designed to serve as a model for performing risk assessments on future traits and crops; examples are provided for the development of a conceptual model, the generation of EECs, possible refinement procedures, and identification of surrogate species using selection criteria. Use of data gathered for the terrestrial ERA informed the aquatic risk assessment by identifying the characteristic of concern, as well as by describing the mode of action, the spectrum of activity, and the stability of proteins in environmental matrices. For Bt maize, we identified exposure pathways (freely soluble protein, POM, or intact plant material) and calculated early tier exposure estimates. Established models and worst-case assumptions were applied, and the resulting EECs for aquatic organisms were very low (low ppb-low ppm). Therefore, we conclude that because the potential exposure of aquatic particle feeders, predators and shredders to insecticidal proteins in current Bt crops is very low, additional hazard testing would not be useful for informing those risk assessments.

Problem formulation will continue to be the critical first step in determining data needs to inform GM crop risk assessments. Crop, trait, and ecosystem characteristics will guide development of a conceptual model and generation of risk hypotheses, and will subsequently aid in the formulation of the analysis plan. We demonstrate application of a tiered approach for exposure assessment, where early tier EECs can be 
refined as necessary by accounting for mitigating factors. Refined aquatic exposure characterization, along with the known specificity of the insecticidal trait and the ecology of aquatic species, may negate the need for hazard tests with surrogate aquatic species. However, for future GM crops, where sufficient spectrum data are lacking and the conceptual model indicates the likelihood for exposure, additional studies, such as those suggested here, may be warranted to adequately characterize risk. This paper illustrates how the processes of problem formulation and exposure characterization should be used to formulate a robust analysis plan and select appropriate surrogate species for hazard testing in future aquatic ERAs.

Acknowledgments The authors wish to acknowledge the Center for Environmental Risk Assessment, ILSI Research Foundation (Washington, DC) and the Agricultural Biotechnology Stewardship Technical Committee on Non-Target Organisms for sponsoring the workshop on Problem Formulation for Biotech Crops and Aquatic Ecosystems, which was the stimulus for this manuscript. We wish to thank Morven McLean, Joel Coats, Rick Hellmich, Tony Shelton, Jeff Wolt, Gary Rand, Sid Abel, Chris Wozniak, Zig Vaituzis, Shannon Borges, Gail Tomimatsu, Joel Gagliardi, Joe Huesing, Rod Herman, Alison Chalmers, and Mike Patnaude for their participation in the discussions leading to this publication and for suggestions to improve the manuscript. Lastly, we wish to acknowledge Kara Califf for her editorial and technical writing contributions, as well as Ray Layton, Alan Raybould, and Chad Boeckman for constructive feedback during the preparation of this manuscript.

Open Access This article is distributed under the terms of the Creative Commons Attribution Noncommercial License which permits any noncommercial use, distribution, and reproduction in any medium, provided the original author(s) and source are credited.

\section{References}

Accinelli C, Koskinen W, Becker JM, Sadowsky MJ (2008) Mineralization of the Bacillus thuringiensis Cry1Ac endotoxin in soil. J Agric Food Chem 56:1025-1028

Allan JD (1995) Stream ecology: structure and function of running waters. Kluwer Academic, Dordrecht, The Netherlands

Allan JD, Castillo MM (2007) Stream ecology; structure and function of running waters, 2nd edn. Springer, Dordrecht

Alstad DN (1987) Particle size, resource concentration, and the distribution of net-spinning caddisflies. Oecologia 71:525531

Arnett RH Jr, Thomas MC, Skelley PE, Frank JH (eds) (2002) American beetles, vol 2. Polyphaga: Scarabaeoidea through Curculionoidea. CRC Press, Boca Raton, xiv $+861 \mathrm{pp}$

Arthur JW, Leonard EN (1970) Effects of copper on Gammarus pseudolimnaeus, Physa integra and Campeloma decisum in soft water. J Fish Res Board Can 27:1277-1283

$\operatorname{ASTM}$ (2008a) Standard test methods for measuring the toxicity of sediment-associated contaminants with freshwater invertebrates. E1706-05. In: ASTM annual book of standards, vol 11.06. American Society for Testing and Materials, Philadelphia, PA

ASTM (2008b) Standard guide for conducting acute toxicity tests on test materials with fishes, macroinvertebrates, and amphibians. E 729-96 (reapproved 2007)

Banks JE, Ackleh A, Stark JD (2010) The use of surrogate species in risk assessment: using life history data to safeguard against false negatives. Risk Anal 30:175-182

Baum JA, Bogaert T, Clinton W, Heck GR, Feldmann P, Ilagan O, Johnson S, Plaetinck G, Munyikwa T, Pleau M, Vaughn T, Roberts J (2007) Control of coleopteran insect pests through RNA interference. Nat Biotechnol 25:1322-1326

Beachy RN, Fedoroff NV, Goldberg RB, McHughen A (2008) The burden of proof: a response to Rosi-Marshall et al. Proc Nat Acad Sci. http://www.pnas.org and http://www.botani schergarten.ch/Bt/Beachy-Rosi-Marshall-Burden-2008.pdf

Becker G (1994) Food preference by five trichopteran scrapers. Hydrobiologia 273:171-178

Benke AC, Wallace JB (1980) Trophic basis of production among net-spinning caddisflies in a southern Appalachian stream. Ecology 61:108-118

Byers GW, Gelhaus JK (2008) Tipulidae. In: Merritt RW, Cummins KW, Berg MB (eds) An introduction to the aquatic insects of North America, 4th edn, revised printing. Kendall/Hunt Publishing Company, Dubuque

CAC (2001) Working principles for application in the framework of the codex alimentarius (adopted by the 26th session of the Codex Alimentarius Commission, Procedural Manual, 13th edn)

Campbell IC, Fuchshuber L (1995) Polyphenols, condensed tannins and processing rates of tropical and temperate leaves in and Australian stream. J N Am Benth Soc 14:174-182

Caro TM, O'Doherty G (1999) On the use of surrogate species in conservation biology. Conserv Biol 13:805-814

Carstens KL, Hayter K, Layton RJ (2010) A perspective on problem formulation and exposure assessment of transgenic crops. IOBC/WPRS Bull 52:23-30

Chen BR, Wise DH (1999) Bottom-up limitation of predaceous arthropods in a detritus-based terrestrial food web. Ecology 80:761-772

Clark BW, Phillips TA, Coats JR (2005) Environmental fate and effects of Bacillus thuringiensis $(\mathrm{Bt})$ proteins from transgenic crops: a review. J Agric Food Chem 53:46454653

Cronan CS, Piampiano JT, Patterson HH (1999) Influence of land use and hydrology on exports of carbon and nitrogen in a Maine river basin. J Environ Qual 28:953-961

Cummins KW, Klug MJ (1979) Feeding ecology of stream invertebrates. Annu Rev Ecol Syst 10:147-172

Cummins KW, Wilzbach MA, Gates DM, Perry JB, Taliaferro WB (1989) Shredders and riparian vegetation. Bioscience 39:24-30 
Cupp EW, Lok JB, Bernardo MJ, Brenner RJ, Pollack RJ, Scoles GA (1981) Complete generation rearing of Simulium damnosum s.l. (Diptera: Simuliidae) in the laboratory. Tropenmed Parasitol 32:119-122

Davis S, Golladay SW, Vellidis G, Pringle CM (2003) Macroinvertebrate biomonitoring in intermittent coastal plain streams impacted by animal agriculture. J Environ Qual 32:1036-1043

Delong MD, Brusven MA (1998) Macroinvertebrate community structure along the longitudinal gradient of an agriculturally impacted stream. Environ Manage 22:445-457

Dieterich M, Anderson N, Anderson T (1997) Shredder-collector interactions in temporary streams of western Oregon. Freshw Biol 38:387-393

Douville M, Gagné F, Blaise C, André C (2007) Occurrence and persistence of Bacillus thuringiensis $(\mathrm{Bt})$ and transgenic $\mathrm{Bt}$ corn cry $1 \mathrm{Ab}$ gene from an aquatic environment. Ecotoxicol Environ Saf 66:195-203

Dutton A, Romeis J, Bigler F (2003) Assessing the risks of insect resistant transgenic plants on entomophagous arthropods: Bt maize expressing Cry1 $\mathrm{Ab}$ as a case study. Biocontrol 48:611-636

EC (European Community) (2001) Directive 2001/18/EC of the European Parliament and of the Council of 12 March 2001 on the deliberate release into the environment of genetically modified organisms and repealing Council Directive 90/220/EEC, European Parliament and the Council of the European Union, Brussels. Off J Eur Commun L106:1-39. http://eur-lex.europa.eu/LexUriServ/LexUriServ.do?uri= CELEX:32001L0018:EN:NOT

EC (European Community) (2003) Guidance document for environmental risk assessments of active substances used on rice in the EU for Annex I inclusion. Document prepared by working group on MED-Rice, EU Document Reference SANCO/1090/2000_rev 1 June 2003. Available at http://ec.europa.eu/food/plant/protection/resources/ med_rice_2003_en.pdf

Effland WR, Thurman NC, Kennedy I (1999) Proposed methods for determining watershed-derived percent cropped areas and considerations for applying crop area adjustments to surface water screening models; USEPA Office of Pesticide Programs; presentation to FIFRA science advisory panel, 27 May 1999

EFSA (European Food Safety Authority) (2010a) EFSA panel on plant protection products and their residues (PPR); scientific opinion on the development of specific protection goal options for environmental risk assessment of pesticides, in particular in relation to the revision of the guidance documents on aquatic and terrestrial ecotoxicology (SANCO/3268/2001 and SANCO/10329/2002). EFSA J 8(10):1821 (55 pp). doi:10.2903/j.efsa.2010.1821. Available online: http://www.efsa.europa.eu/efsajournal.htm

EFSA (European Food Safety Authority) (2010b) EFSA panel on genetically modified organisms (GMO); scientific opinion on the assessment of potential impacts of genetically modified plants on non-target organisms. EFSA J 8(11):1877 (72 pp). doi:10.2903/j.efsa.2010.1877. Available online: http://www.efsa.europa.eu/efsajournal.htm

Favreau JM, Drew CA, Hess GR, Rubino MJ, Koch FH, Eschelbach KA (2006) Recommendations for assessing the effectiveness of surrogate species approaches. Biodivers Conserv 15:3949-3969

FOCUS (2003) FOCUS surface water scenarios in the EU evaluation process under 91/414/EEC. Report of the FOCUS working group on surface water scenarios, EC Document Reference SANCO/4802/2001-rev.2, 245 pp

Garcia-Alonso M, Jacobs E, Raybould A, Nickson TE, Sowig P, Willekens H, Van der Kouwe P, Layton R, Amijee F, Fuentes AM, Tencalla F (2006) A tiered system for assessing the risk of genetically modified plants to non-target organisms. Environ Biosaf Res 5:57-65

GBIF Data Portal (2011) Caecidotea communis. http://data. gbif.org. Accessed 23 Feb 2011

George C, Ridley WP, Obert JC, Nemeth MA, Breeze ML, Astwood JD (2004) Composition of grain and forage from corn rootworm-protected corn event MON 863 is equivalent to that of conventional corn (Zea mays L.). J Agric Food Chem 52:4149-4158

Georgian TJ, Wallace JB (1981) A model of seston capture by net-spinning caddisflies. Oikos 36:147-157

Gregory SV, Swanson FJ, McKee WA, Cummins KW (1991) An ecosystem perspective of riparian zones. Bioscience 41:540-551

Griffiths NA, Tank JL, Royer TV, Rosi-Marshall EJ, Whiles MR, Chambers CP, Frauendorf TC, Evans-White MA (2009) Rapid decomposition of maize detritus in agricultural headwater streams. Ecol Appl 19:133-142

Hargrave BT (1970) The utilization of benthic microflora by Hyalella azteca (Amphipoda). J Anim Ecol 39:427-437

Harwood JD, Wallin WG, Obrycki JJ (2005) Uptake of Bt endotoxins by nontarget herbivores and higher order arthropod predators: molecular evidence from a transgenic corn agroecosystem. Mol Ecol 14:2815-2823

Head G, Surber JB, Watson JA, Martin JW, Duan JJ (2002) No detection of Cry1Ac protein in soil after multiple years of transgenic Bt cotton (Bollgard) use. Environ Entomol 31:30-36

Heatherly T II, Whiles MR (2007) Relationships between water quality, habitat quality, and macroinvertebrate assemblages in Illinois streams. J Environ Qual 36:1653-1660

Herman RA, Evans SL, Shanahan DM, Mihaliak CA, Bormett GA, Young DL, Buehrer J (2001) Rapid degradation of Cry1F delta-endotoxin in soil. Environ Entomol 30:642-644

Herman RA, Chassy BM, Parrott W (2009) Compositional assessment of transgenic crops: an idea whose time has passed. Trends Biotechnol 27:555-557

Herzon I, Helenius J (2008) Agricultural drainage ditches, their biological importance and functioning. Biol Conserv 141:1171-1183

Hoang TC, Rand GM (2009) Exposure routes of copper: short term effects on survival, weight, and uptake in Florida apple snails (Pomacea paludosa). Chemosphere 76:407-414

Hopkins DW, Gregorich EG (2003) Detection and decay of the $B t$ endotoxin in soil from a field trial with genetically modified maize. Eur J Soil Sci 54:793-800

HSNO (1996) Hazardous Substances and New Organisms Act 1996. http://www.legislation.govt.nz/act/public/1996/0030/ latest/DLM381222.html?search=ts_act_hazardous + substances+organisms_resel $\& \mathrm{p}=1 \& \mathrm{sr}=1$ 
Icoz I, Stotzky G (2007) Cry3Bb1 protein from Bacillus thuringiensis in root exudates and biomass of transgenic corn does not persist in soil. Transgenic Res 17:609-620

Icoz I, Stotzky G (2008) Fate and effects of insect-resistant Bt crops in soil ecosystems. Soil Biol Biochem 40:559-586

Israelsen C, Barnhill J, Pace M, Greenhalgh L, Gale J (2009) Harvesting corn silage by plant moisture. http://extension. usu.edu/files/publications/publication/AG_Faramaland_ 2009-03pr.pdf

Iversen TM (1974) Ingestion and growth in Sericostoma personatum (Trichoptera) in relation to the nitrogen content of ingested leaves. Oikos 25:278-282

Jackson RB, Carpenter SR, Dahm CN, McKnight DM, Naiman RJ, Postel SL, Running SW (2001) Water in a changing world. Ecol Appl 11:1027-1045

James C (2009) Global status of commercialized biotech/GM crops: 2010. ISAAA Briefs No. 42 ISAAA, Ithaca, NY, USA

Jensen PD, Dively GP, Swan CM, Lamp WO (2010) Exposure and non-target effects of transgenic Bt corn debris in streams. Environ Entomol 39:707-714

Johnson SL, Covich AP (1997) Scales of observation of riparian forests and distributions of suspended detritus in a prairie river. Freshw Biol 37:163-175

Klug MJ, Cummins KW (1979) Feeding ecology of stream invertebrates. Annu Rev Ecol Syst 10:147-172

Lacey LA, Mulla MS (1977) A new bioassay unit for evaluating larvicides against blackflies. J Econ Entomol 70:453-456

Lenat DR, Crawford JK (1994) Effects of land use on water quality and aquatic biota of three North Carolinian Piedmont streams. Hydrobiologia 294:185-199

Levin SA, Norberg J, Swaney DP, Dushoff J, Lin J, Casagrandi R (2001) Phenotypic diversity and ecosystem functioning in changing environments: a theoretical framework. Proc Natl Acad Sci USA 98:11376-11381

Li Y, Wu K, Zhang Y, Yuan G (2007) Degradation of Cry1Ac protein within transgenic Bacillus thuringiensis rice tissues under field and laboratory conditions. Environ Entomol 36:1275-1282

Li Y, Meissle M, Romeis J (2010) Use of maize pollen by adult Chrysoperla carnea (Neuroptera: Chrysopidae) and fate of Cry proteins in $B t$ transgenic varieties. J Insect Physiol 56:157-164

Lowry J (2010) Hyalella azteca (Saussure, 1858). In: Lowry J (ed) World amphipoda database. Accessed through: World Register of Marine Species at http://www.marinespecies. org/aphia.php? $\mathrm{p}=$ taxdetails\&id=158105 on $21 \mathrm{Feb} 2011$

Malone LA, Gatehouse AMR, Barratt BIP (2008) Beyond Bt: alternative strategies for insect-resistant genetically modified crops. In: Romeis J, Shelton AM, Kennedy GG (eds) Integration of insect-resistant genetically modified crops within IPM programs. Springer Science + Business Media B.V., Berlin, pp 357-417

Marchetti E, Accinelli C, Talame V, Epifani R (2007) Persistence of cry toxins and cry genes from genetically modified plants in two agricultural soils. Agron Sustain Dev 27:231-236

Mayer PM, Reynolds SK Jr, Canfield TJ, McCutchen MD (2005) Riparian buffer width, vegetative cover, and nitrogen removal effectiveness: a review of current science and regulations. USEPA, Cincinnati
Mecom JO (1972) Feeding habits of Trichoptera in a mountain stream. Oikos 23:401-407

Meissle M, Romeis J (2009) The web-building spider Theridion impressum (Araneae: Theridiidae) is not adversely affected by $B t$ maize resistant to corn rootworms. Plant Biotech $\mathrm{J}$ 7:645-656

Menninger HL, Palmer MA (2007) Herbs and grasses as an allochthonous resource in open-canopy headwater streams. Freshw Biol 52:1689-1699

Merritt RW, Cummins KW, Berg MB (2008) An introduction to the aquatic insects of North America, 4th edn, revised printing. Kendall/Hunt Publishing Company, Dubuque

Miethling-Graff R, Dockhorn S, Tebbe CC (2010) Release of the recombinant Cry3Bb1 protein of Bt maize MON88017 into field soil and detection of effects on the diversity of rhizosphere bacteria. Eur J Soil Biol 46:41-48

Miller J, Georgian T (1992) Estimation of fine particulate transport in streams using pollen as a seston analog. J N Am Benth Soc 11:172-180

Moore AA, Palmer MA (2005) Invertebrate biodiversity in agricultural and urban headwater streams: implications for conservation and management. Ecol Appl 15:1169-1177

NASS (2010) Corn acreage planted for all purposes by state and United States, 2009-2010. The National Agricultural Statistics Service (NASS) June Data Agriculture Survey, Agricultural Statistics Service, US Department of Agriculture. Approved 30 June 2010. Available on the NASS website: http://www.nass.usda.gov

Nguyen HT, Jehle JA (2007) Quantitative analysis of the seasonal and tissue-specific expression of Cry $1 \mathrm{Ab}$ in transgenic maize Mon810. J Plant Dis Protect 114:82-87

Nguyen HT, Jehle JA (2009) Expression of Cry3Bb1 in transgenic corn MON88017. J Agric Food Chem 57:9990-9996

NRC (2010) The impact of genetically engineered crops on farm sustainability in the United States. National Research Council of the National Academies. The National Academies Press, Washington, DC

Obrist LB, Dutton A, Albajes R, Bigler F (2006) Exposure of arthropod predators to Cry1 $\mathrm{Ab}$ toxin in $\mathrm{Bt}$ maize fields. Ecol Entomol 31:143-154

OECD (2004a) Guidelines for the testing of chemicals/section 2: effects on biotic systems. Test No. 219: sedimentwater chironomid toxicity using spiked water. Organisation for Economic Co-operation and Development, Paris

OECD (2004b) Guidelines for the testing of chemicals/section 2: effects on biotic systems. Test No. 202: Daphnia sp. Acute immobilisation test. Organisation for Economic Cooperation and Development, Paris

OECD (2007) Consensus document on safety information on transgenic plants expressing Bacillus thuringiensisderived insect control protein. Series on harmonisation of regulatory oversight in biotechnology, No. 42. Organisation for Economic Co-operation and Development, Paris. http://www.olis.oecd.org/olis/2007doc.nsf/LinkTo/NT000 02DF6/\$FILE/JT03230592.PDF. Accessed 11 June 2010

Office of Legislative Drafting, Attorney-General's Department, Canberra, Australia (2000) Gene Technology Act 2000 (No. 169). http://www.brad.ac.uk/acad/sbtwc/btwc/nat_ imp/leg_reg/australia/GeneTechnology2000.pdf

Parrott W (2008) Study of Bt impact on caddisflies overstates its conclusions: response to Rosi-Marshall et al. Proc Natl 
Acad Sci. http://www.pnas.org and http://www.botanis chergarten.ch/Bt/Parrott-Rosi-Marshall-2008.pdf

Pesacreta GJ (1997) Response of the stonefly Pteronacys dorsata in enclosures from an urban North Carolina stream. Bull Environ Contam Toxicol 59:948-955

Peterson JL, Jepson PC, Jenkins JJ (2001) Effect of varying pesticide exposure duration and concentration on the toxicity of carbaryl to two field collected stream invertebrates, Calineura californica (Plecoptera: Perlidae) and Cinygma sp. (Ephemeroptera: Heptageniidae). Env Toxicol Chem 20:2215-2223

Pieterse NM, Bleuten W, Jørgensen SE (2003) Contribution of point sources and diffuse sources to nitrogen and phosphorus loads in lowland river tributaries. J Hydrol 271: 213-225

Pinder LCV (1986) Biology of freshwater chironomidae. Annu Rev Entomol 31:1-23

Ponsard S, Arditi R, Jost C (2000) Assessing top-down and bottom-up control in a litter-based soil macroinvertebrate food chain. Oikos 89:524-540

Pote J, Ackermann R, Wildi W (2009) Plant leaf mass loss and DNA release in freshwater sediments. Ecotoxicol Environ Saf 72:1378-1383

Prihoda KR, Coats JR (2008a) Aquatic fate and effects of Bacillus thuringiensis $\mathrm{Cry} 3 \mathrm{Bb} 1$ protein: toward risk assessment. Environ Toxicol Chem 27:793-798

Prihoda KR, Coats JR (2008b) Fate of Bacillus thuringiensis Cry3Bb1 protein in a soil microcosm. Chemosphere 73:1102-1107

Rauschen S, Schaarschmidt F, Gathmann A (2010) Occurrence and field densities of Coleoptera in the maize herb layer: implications for environmental risk assessment of genetically modified Bt-maize. Transgenic Res 19:727744

Raybould A (2006) Problem formulation and hypothesis testing for environmental risk assessments of genetically modified crops. Environ Biosaf Res 5:119-125

Raybould A (2007) Environmental risk assessment of genetically modified crops: general principles and risks to nontarget organisms. BioAssay 2:8. Available online at: http://www.seb.org.br/bioassay

Raybould A (2010) Reducing uncertainty in regulatory decision-making for transgenic crops. More ecological research or clearer environmental risk assessment? GM Crops 1:25-31

Raybould A, Vlachos D (2011) Non-target organism effects tests on Vip3A and their application to the ecological risk assessment for cultivation of MIR162 maize. Transgenic Res 20:599-611

Raybould A, Stacey D, Vlachos D, Graser G, Li X, Joseph R (2007) Non-target organism risk assessment of MIR604 maize expressing mCry $3 \mathrm{~A}$ for control of corn rootworms. J Appl Entomol 131:391-399

Raybould A, Tuttle A, Shore S, Stone T (2010) Environmental risk assessments for transgenic crops producing output trait enzymes. Transgenic Res 19:595-609

Ridley WP, Sidhu RS, Pyla PD, Nemeth MA, Breeze ML, Astwood JD (2002) Comparison of the nutritional profile of glyphosate-tolerant corn event NK603 with that of conventional corn (Zea mays L.). J Agric Food Chem 50:7235-7243
Romeis J, Bartsch D, Bigler F, Candolfi MP, Gielkens MMC, Hartley SE, Hellmich RL, Huesing JE, Jepson PC, Layton R, Quemada H, Raybould A, Rose RI, Schiemann J, Sears MK, Shelton AM, Sweet J, Vaituzis Z, Wolt JD (2008) Assessment of risk of insect-resistant transgenic crops to nontarget arthropods. Nat Biotechnol 26:203-208

Romeis J, Meissle M, Raybould A, Hellmich RL (2009) Impact of insect-resistant transgenic crops on above-ground nontarget arthropods. In: Ferry N, Gatehouse AMR (eds) Environmental impact of genetically modified crops. CABI, Wallingford, pp 165-198

Romeis J, Hellmich RL, Candolfi MP, Carstens K, De Schrijver A, Gatehouse AMR, Herman R, Huesing JE, McLean MA, Raybould A, Shelton AM, Waggoner A (2011) Recommendations for the design of laboratory studies on nontarget arthropods for risk assessment of genetically engineered plants. Transgenic Res 20:1-22

Rose RI (ed) (2007) White paper on tier-based testing for the effects of proteinaceous insecticidal plant-incorporated protectants on non-target invertebrates for regulatory risk assessment. USDA-APHIS and US Environmental Protection Agency, Washington, DC, USA. http://www.epa. gov/pesticides/biopesticides/pips/non-target-arthropods. pdf

Rosi-Marshall EJ, Tank JL, Royer TV, Whiles MR, EvansWhite M, Chambers C, Griffiths NA, Pokelsek J, Stephen ML (2007) Toxins in transgenic crop byproducts may affect headwater stream ecosystems. Proc Natl Acad Sci USA 104:16204-16208

Sanvido O, Romeis J, Gathmann A, Gielkens M, Raybould A, Bigler F (2011) Evaluating environmental risks of genetically modified crops: ecological harm criteria for regulatory decision-making. Environ Sci Policy. doi:10.1016/ j.envsci.2011.08.006

Secretariat of the Convention on Biological Diversity (SCBD) (2000) Cartagena Protocol on Biosafety to the convention on biological diversity: text and annexes. Secretariat of the Convention on Biological Diversity, Montreal

Sims SR, Holden LR (1996) Insect bioassay for determining soil degradation of Bacillus thuringiensis subsp. kurstaki CryIA(b) protein in corn tissue. Environ Entomol 25:659-664

Smith RL (1992) Elements of ecology, 3rd edn. HarperCollins, New York, pp 563-567

Solis MA (2008) Aquatic and semiaquatic Lepidoptera. In: Merritt RW, Cummins KW, Berg MB (eds) An introduction to the aquatic insects of North America, 4th edn, revised printing. Kendall/Hunt Publishing Company, Dubuque

Stone ML, Whiles MR, Webber JA, Williard KWJ, Reeve JD (2005) Macroinvertebrate communities in agriculturally impacted southern Illinois streams: patterns with riparian vegetation, water quality, and in-stream habitat quality. J Environ Qual 34:907-917

Stotzky G (2002) Release, persistence, and biological activity in soil of insecticidal proteins from Bacillus thuringiensis. In: Letourneau DK, Burrows BE (eds) Genetically engineered organisms: assessing environmental and human health effects. CRC Press, Boca Raton, pp 187-222

Swan CM, Palmer MA (2004) Leaf diversity alters litter breakdown in a Piedmont stream. J N Am Benthol Soc 23:15-28 
Swan CM, Jensen PD, Dively GP, Lamp WO (2009) Processing of transgenic crop residues in stream ecosystems. J Appl Ecol 46:1304-1313

Tank JL, Rosi-Marshall EJ, Royer TV, Whiles MR, Griffiths NA, Frauendorf TC, Treering DJ (2010) Occurrence of maize detritus and a transgenic insecticidal protein $(\mathrm{Cry} 1 \mathrm{Ab})$ within the stream network of an agricultural landscape. Proc Natl Acad Sci USA 107:17645-17650

Taylor NB, Fuchs RL, MacDonald J, Shariff AR, Padgette SR (1999) Compositional analysis of glyphosate-tolerant soybeans treated with glyphosate. J Agric Food Sci 47: 4469-4473

Thompson FG (1984) The freshwater snails of Florida: a manual for identification. University of Florida Press, Gainesville

US EPA (1998) Guidelines for ecological risk assessment. US EPA 630/R-95-002F, Washington, DC

US EPA (2000) Methods for measuring the toxicity and bioaccumulation of sediment-associated contaminants with freshwater invertebrates, 2nd edn. US EPA/600/R-99/064, Duluth, MN

US EPA (2001) Biopesticides registration action document for the Bacillus thuringiensis (Bt) plant-incorporated protectants. 15 Oct 2001 US EPA, Washington, DC. http://www. epa.gov/oppbppd1/biopesticides/pips/bt_brad.htm

US EPA (2002a) Guidance for selecting input parameters in modeling the environmental fate and transport of pesticides. U.S. Environmental Protection Agency, Office of Prevention, Pesticides and Toxic Substances, Office of Pesticide Programs, Environmental Fate and Effects Division; 28 Feb 2002. http://www.epa.gov/oppefed1/ models/water/input_guidance2_28_02.htm

US EPA (2002b) Methods for measuring the acutetoxicity of effluents and receiving waters to freshwater and marine organisms. EPA-821-R-02-012

US EPA (2004) Overview of the ecological risk assessment process in the office of pesticide programs, endangered and threatened species effects determinations. US EPA, Washington, DC

US Endangered Species Act (1973) 16 U.S.C. $§ 1531$ et seq

US Federal Insecticide, Fungicide, and Rodenticide Act of 1947 (2004) 7 U.S.C. $\S 136$ et seq

USDA (1982) Ponds-planning design, construction. USDA, Soil Conservation Service. Agricultural Handbook number 450. US Government Printing Office, Washington, DC

Usio N, Townsend CR (2001) The significance of the crayfish Paranephrops zealandicus as shredders in a New Zealand headwater stream. J Crustac Biol 21:354-359

Van Frankenhuyzen K (2010) Insecticidal activity of Bacillus thuringiensis crystal proteins. J Invertebr Pathol 101:1-16
Vannote RL, Sweeney BW (1985) Larval feeding and growth rate of the stream cranefly Tipula abdominalis in gradients of temperature and nutrition. Proc Acad Natl Sci Phila 137:119-128

Wallace JB, Eggert SL, Meyer JL, Webster JR (1997) Multiple trophic levels of a forest stream linked to terrestrial litter inputs. Science 277:102-104

Waltz RD, Burian SK (2008) Ephemeroptera. In: Merritt RW, Cummins KW, Berg MB (eds) An introduction to the aquatic insects of North America, 4th edn. Revised printing, Kendall/Hunt Publishing Co., Dubuque, Iowa

Webster JR, Benfield EF (1986) Vascular plant breakdown in freshwater ecosystems. Annu Rev Ecol Syst 17:567-594

White DS, Roughley RE (2008) Aquatic Coleoptera. In: An introduction to the aquatic insects of North America. Merritt RW, Cummins KW, Berg MB (eds) 4th edn, revised printing, Kendall/Hunt Publihing Company, Dubuque

Wiggins GB (1959) A method for rearing caddisflies (Trichoptera). Can Entomol 91:402-405

Williams WD (1972) Freshwater isopods (Assellidae) of North America. Biota of freshwater ecosystems identification manual no. 7. US EPA

Wirth MC, Yang Y, Walton WE, Federici BA, Berry C (2007) Mtx toxins synergize Bacillus sphaericus and Cry11Aa against susceptible and insecticide resistant Culex quinquefasciatus larvae. Appl Environ Microbiol 73:60666071

Wolt JD (2009) Advancing environmental risk assessment for transgenic biofeedstock crops. Biotechnol Biofuels 2:27

Wolt JD, Peterson RKD (2010) Prospective formulation of environmental risk assessments: probabilistic screening for Cry1A(b) maize risk to aquatic insects. Ecotoxicol Environ Saf 73:1182-1188

Wolt JD, Conlan CA, Majima K (2005) An ecological risk assessment of Cry1F maize pollen impact to pale grass blue butterfly. Environ Biosaf Res 4:243-251

Wolt JD, Keese P, Raybould A, Fitzpatrick JW, Burachik M, Gray A, Olin SS, Schiemann J, Sears M, Wu F (2010) Problem formulation in the environmental risk assessment for genetically modified plants. Transgenic Res 19: 425-436

Zurbrügg C, Höhnemann L, Meissle M, Romeis J, Nentwig W (2010) Decomposition dynamics and structural plant components of genetically modified $B t$ maize leaves do not differ from conventional hybrids. Transgenic Res 19:257267 